\title{
LEVEL II SCOUR ANALYSIS FOR BRIDGE 25 (CLARTH00100025) on TOWN HIGHWAY 10, crossing the CLARENDON RIVER, CLARENDON, VERMONT
}

U.S. Geological Survey Open-File Report 96-636

Prepared in cooperation with

VERMONT AGENCY OF TRANSPORTATION and

FEDERAL HIGHWAY ADMINISTRATION 


\title{
LEVEL II SCOUR ANALYSIS FOR BRIDGE 25 (CLARTH00100025) on TOWN HIGHWAY 10, crossing the CLARENDON RIVER, CLARENDON, VERMONT
}

\author{
By JOSEPH D. AYOTTE
}

U.S. Geological Survey Open-File Report 96-636

Prepared in cooperation with

VERMONT AGENCY OF TRANSPORTATION and

FEDERAL HIGHWAY ADMINISTRATION 


\title{
U.S. DEPARTMENT OF THE INTERIOR BRUCE BABBITT, Secretary
}

\author{
U.S. GEOLOGICAL SURVEY \\ Gordon P. Eaton, Director
}

For additional information write to:

District Chief

U.S. Geological Survey 361 Commerce Way

Pembroke, NH 03275-3718
Copies of this report may be purchased from:

U.S. Geological Survey

Branch of Information Services

Open-File Reports Unit

Box 25286

Denver, CO 80225-0286 


\section{CONTENTS}

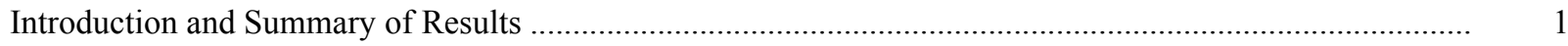

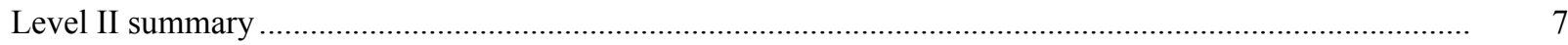

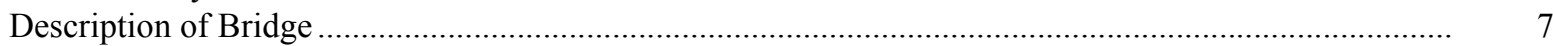

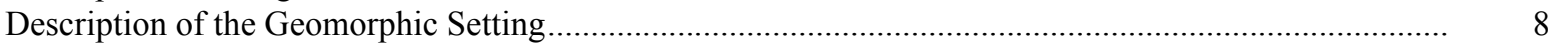

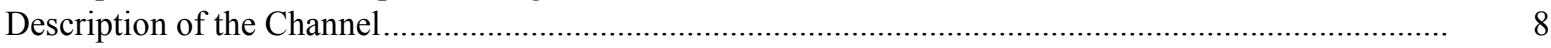

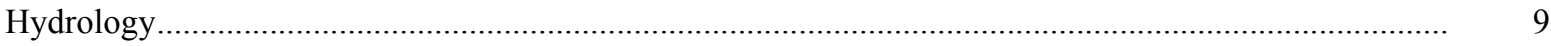

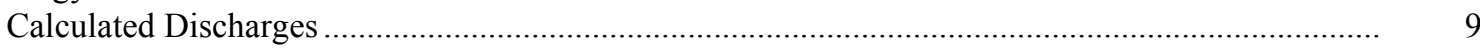

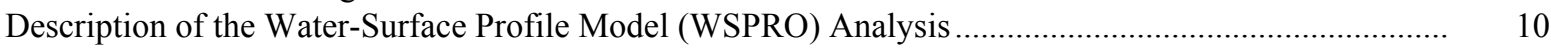

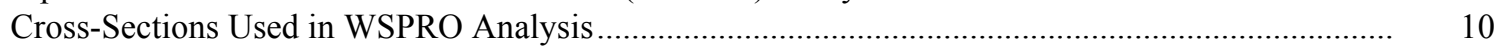

Data and Assumptions Used in WSPRO Model ...................................................................... 11

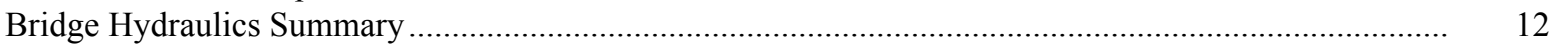

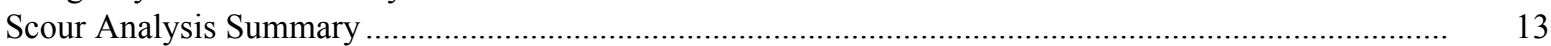

Special Conditions or Assumptions Made in Scour Analysis ...................................................... 13

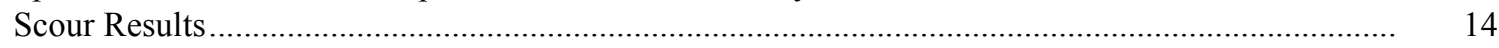

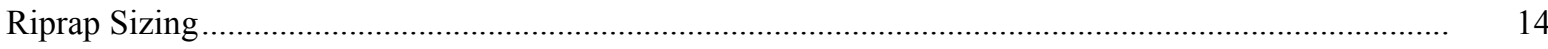

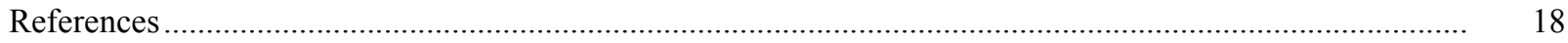

Appendixes:

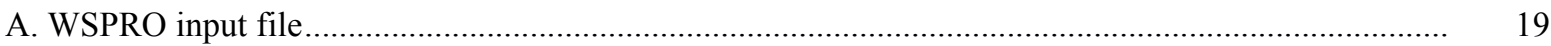

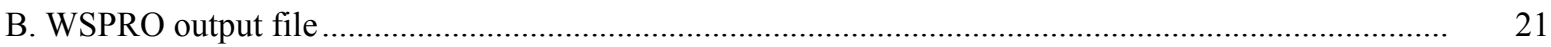

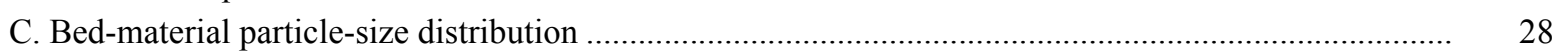

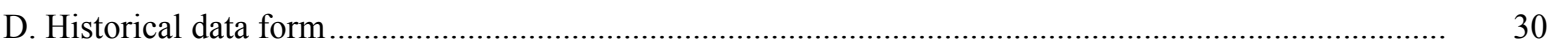

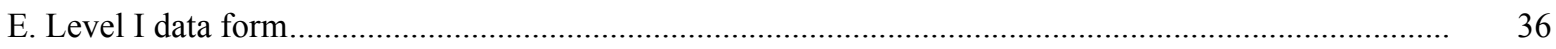

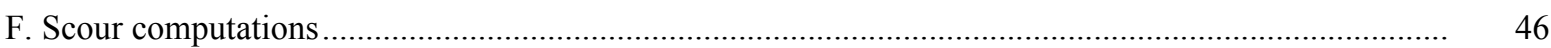

\section{FIGURES}

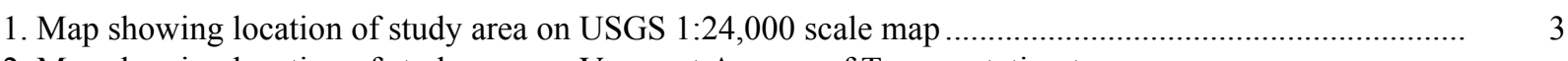

2. Map showing location of study area on Vermont Agency of Transportation town
highway map

3. Structure CLARTH00100025 viewed from upstream (April 27, 1995) ................................................. 5

4. Downstream channel viewed from structure CLARTH00100025 (April 27, 1995)............................. 5

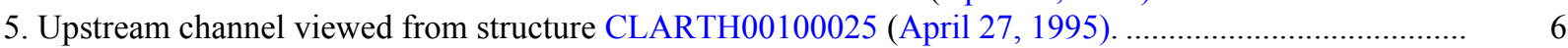

6. Structure CLARTH00100025 viewed from right road approach (April 27, 1995)............................... 6

7. Water-surface profiles for the 100- and 500-year discharges at structure

CLARTH00100025 on Town Highway 10, crossing the Clarendon River,

Clarendon, Vermont.

8. Scour elevations for the 100- and 500-year discharges at structure

CLARTH00100025 on Town Highway 10, crossing the Clarendon River,

Clarendon, Vermont.

\section{TABLES}

1. Remaining footing/pile depth at abutments for the 100-year discharge at structure

CLARTH00100025 on Town Highway 10, crossing the Clarendon River,

Clarendon, Vermont.

2. Remaining footing/pile depth at abutments for the 500-year discharge at structure

CLARTH00100025 on Town Highway 10, crossing the Clarendon River,

Clarendon, Vermont...

3
5
5
6
(5 


\begin{tabular}{|c|c|c|}
\hline Multiply & By & To obtain \\
\hline \multicolumn{3}{|c|}{ Length } \\
\hline inch (in.) & 25.4 & millimeter (mm) \\
\hline foot $(\mathrm{ft})$ & 0.3048 & $\operatorname{meter}(\mathrm{m})$ \\
\hline mile (mi) & 1.609 & kilometer (km) \\
\hline \multicolumn{3}{|c|}{ Slope } \\
\hline foot per mile ( $\mathrm{ft} / \mathrm{mi})$ & 0.1894 & meter per kilometer $(\mathrm{m} / \mathrm{km})$ \\
\hline \multicolumn{3}{|c|}{ Area } \\
\hline square mile $\left(\mathrm{mi}^{2}\right)$ & 2.590 & square kilometer $\left(\mathrm{km}^{2}\right)$ \\
\hline \multicolumn{3}{|c|}{ Volume } \\
\hline cubic foot $\left(\mathrm{ft}^{3}\right)$ & $\begin{array}{l}0.02832 \\
\text { Velocity and Flow }\end{array}$ & cubic meter $\left(\mathrm{m}^{3}\right)$ \\
\hline foot per second $(\mathrm{ft} / \mathrm{s})$ & 0.3048 & meter per second $(\mathrm{m} / \mathrm{s})$ \\
\hline cubic foot per second $\left(\mathrm{ft}^{3} / \mathrm{s}\right)$ & 0.02832 & cubic meter per second $\left(\mathrm{m}^{3} / \mathrm{s}\right)$ \\
\hline $\begin{array}{l}\text { cubic foot per second per } \\
\text { square mile } \\
{\left[\left(\mathrm{ft}^{3} / \mathrm{s}\right) / \mathrm{mi}^{2}\right]}\end{array}$ & 0.01093 & $\begin{array}{l}\text { cubic meter per } \\
\text { second per square } \\
\text { kilometer }\left[\left(\mathrm{m}^{3} / \mathrm{s}\right) / \mathrm{km}^{2}\right]\end{array}$ \\
\hline
\end{tabular}

OTHER ABBREVIATIONS

$\begin{array}{lrlr}\mathrm{BF} & \text { bank full } & \text { LWW } & \text { left wingwall } \\ \mathrm{cfs} & \text { cubic feet per second } & \text { MC } & \text { main channel } \\ \mathrm{D}_{50} & \text { median diameter of bed material } & \text { RAB } & \text { right abutment } \\ \mathrm{DS} & \text { downstream } & \text { RABUT } & \text { face of right abutment } \\ \mathrm{elev} & \text { elevation } & \text { RB } & \text { right bank } \\ \mathrm{f} / \mathrm{p} & \text { flood plain } & \text { ROB } & \text { right overbank } \\ \mathrm{ft} & \text { square feet } & \text { RWW } & \text { right wingwall } \\ \mathrm{ft} / \mathrm{ft} & \text { feet per foot } & \text { TH } & \text { town highway } \\ \mathrm{JCT} & \text { junction } & \text { UB } & \text { under bridge } \\ \mathrm{LAB} & \text { left abutment } & \text { US } & \text { upstream } \\ \mathrm{LABUT} & \text { face of left abutment } & \text { USGS } & \text { United States Geological Survey } \\ \text { LB } & \text { left bank } & \text { VTAOT Vermont Agency of Transportation } \\ \text { LOB } & \text { left overbank } & \text { WSPRO } & \text { water-surface profile model }\end{array}$

In this report, the words "right" and "left" refer to directions that would be reported by an observer facing downstream. Sea level: In this report, "sea level" refers to the National Geodetic Vertical Datum of 1929-- a geodetic datum derived from a general adjustment of the first-order level nets of the United States and Canada, formerly called Sea Level Datum of 1929.

In the appendices, the above abbreviations may be combined. For example, USLB would represent upstream left bank. 


\title{
LEVEL II SCOUR ANALYSIS FOR BRIDGE 25 (CLARTH00100025) ON TOWN HIGHWAY 10, CROSSING THE CLARENDON RIVER, CLARENDON, VERMONT
}

\author{
By Joseph D. Ayotte
}

\section{INTRODUCTION AND SUMMARY OF RESULTS}

This report provides the results of a detailed Level II analysis of scour potential at structure CLARTH00100025 on town highway 10 crossing the Clarendon River, Clarendon, Vermont (figures 1-8). A Level II study is a basic engineering analysis of the site, including a quantitative analysis of stream stability and scour (U.S. Department of Transportation, 1993). Resultsof a Level I scour investigation also are included in Appendix E of this report. A Level I study provides a qualitative geomorphic characterization of the study site. Information on the bridge, gleaned from Vermont Agency of Transportation (VTAOT) files, was compiled prior to conducting Level I and Level II analyses and is found in Appendix D.

The site is in the Taconic Section of the New England physiographic province in westcentral Vermont. The $19.3-\mathrm{mi}^{2}$ drainage area is in a predominantly rural basin. In the vicinity of the study site, the left and right banks are covered by pasture and (or) fields. The right bank of Clarendon River is eroded due to stream-flow attack immediately upstream of the bridge.

In the study area, the Clarendon River has a sinuous channel with a slope of approximately $0.007 \mathrm{ft} / \mathrm{ft}$, an average channel top width of $44 \mathrm{ft}$ and an average channel depth of $3 \mathrm{ft}$. There are large meanders approximately 100 feet upstream and downstream of the bridge. The predominant channel bed materials are gravel and cobbles with a median grain size $\left(\mathrm{D}_{50}\right)$ of $42.4 \mathrm{~mm}(0.139 \mathrm{ft})$. The geomorphic assessment at the time of the Level I and Level II site visit on April 27, 1995, indicated that the reach was laterally unstable.

The town highway 10 crossing of the Clarendon River was a 27-ft-long, two-lane bridge consisting of one 24-foot steel stringer with a timber deck (Vermont Agency of Transportation, written communication, March 13, 1995). The deck was removed at the time of the survey but the analysis was done as if the old deck was in place. The bridge is supported on the left by a vertical stone abutment and on the right by a vertical, concrete abutment with an upstream wingwall. The channel is skewed approximately 10 degrees to the opening while the opening-skew-to-roadway is 0 degrees. 
A scour hole $3 \mathrm{ft}$ deeper than the mean thalweg depth was observed along the right bank extending from 24 to 60 feet upstream of the bridge. No scour prevention measures were observed at this site at the time of the site visit. Additional details describing conditions at the site are included in the Level II Summary and Appendices D and E.

Scour depths and rock rip-rap sizes were computed using the general guidelines described in Hydraulic Engineering Circular 18 (Richardson and others, 1995). Total scour at a highway crossing is comprised of three components: 1) long-term streambed degradation; 2) contraction scour (due to accelerated flow caused by a reduction in flow area at a bridge) and; 3) local scour (caused by accelerated flow around piers and abutments). Total scour is the sum of the three components. Equations are available to compute depths for contraction and local scour and a summary of the results of these computations follows.

Contraction scour for all modelled flows ranged from 0.0 to $0.8 \mathrm{ft}$. The worst-case contraction scour occurred at the 500-year discharge. Abutment scour ranged from 5.7 to $10.6 \mathrm{ft}$. The worst-case abutment scour also occurred at the 500-year discharge. Additional information on scour depths and depths to armoring are included in the section titled "Scour Results". Scoured-streambed elevations, based on the calculated scour depths, are presented in tables 1 and 2. A cross-section of the scour computed at the bridge is presented in figure 8. Scour depths were calculated assuming an infinite depth of erosive material and a homogeneous particle-size distribution.

It is generally accepted that the Froehlich equation (abutment scour) gives "excessively conservative estimates of scour depths" (Richardson and others, 1995, p. 47). Usually, computed scour depths are evaluated in combination with other information including (but not limited to) historical performance during flood events, the geomorphic stability assessment, existing scour protection measures, and the results of the hydraulic analyses. Therefore, scour depths adopted by VTAOT may differ from the computed values documented herein. 


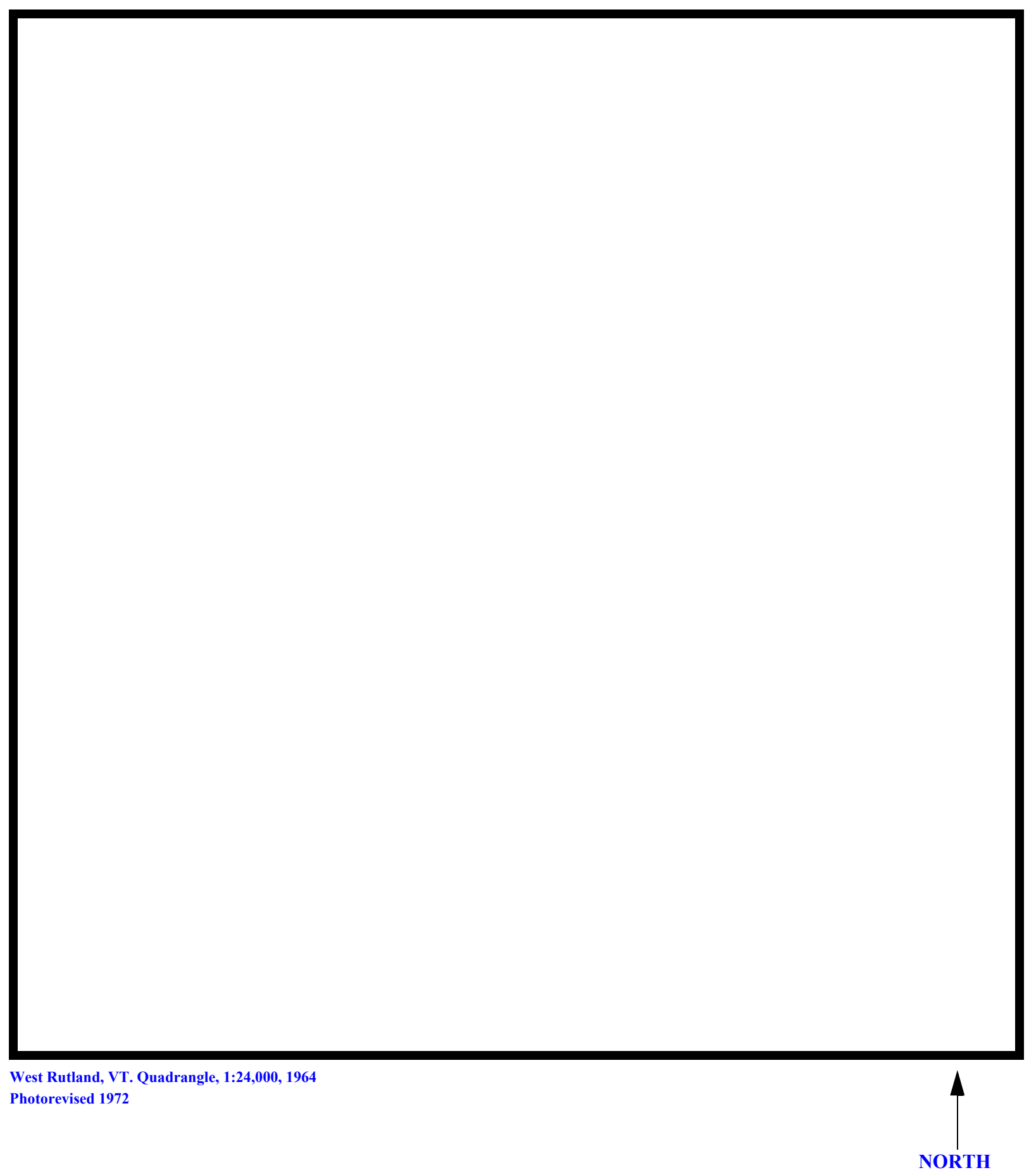

Figure 1. Location of study area on USGS 1:24,000 scale map. 
Figure 2. Location of study area on Vermont Agency of Transportation town highway map. 

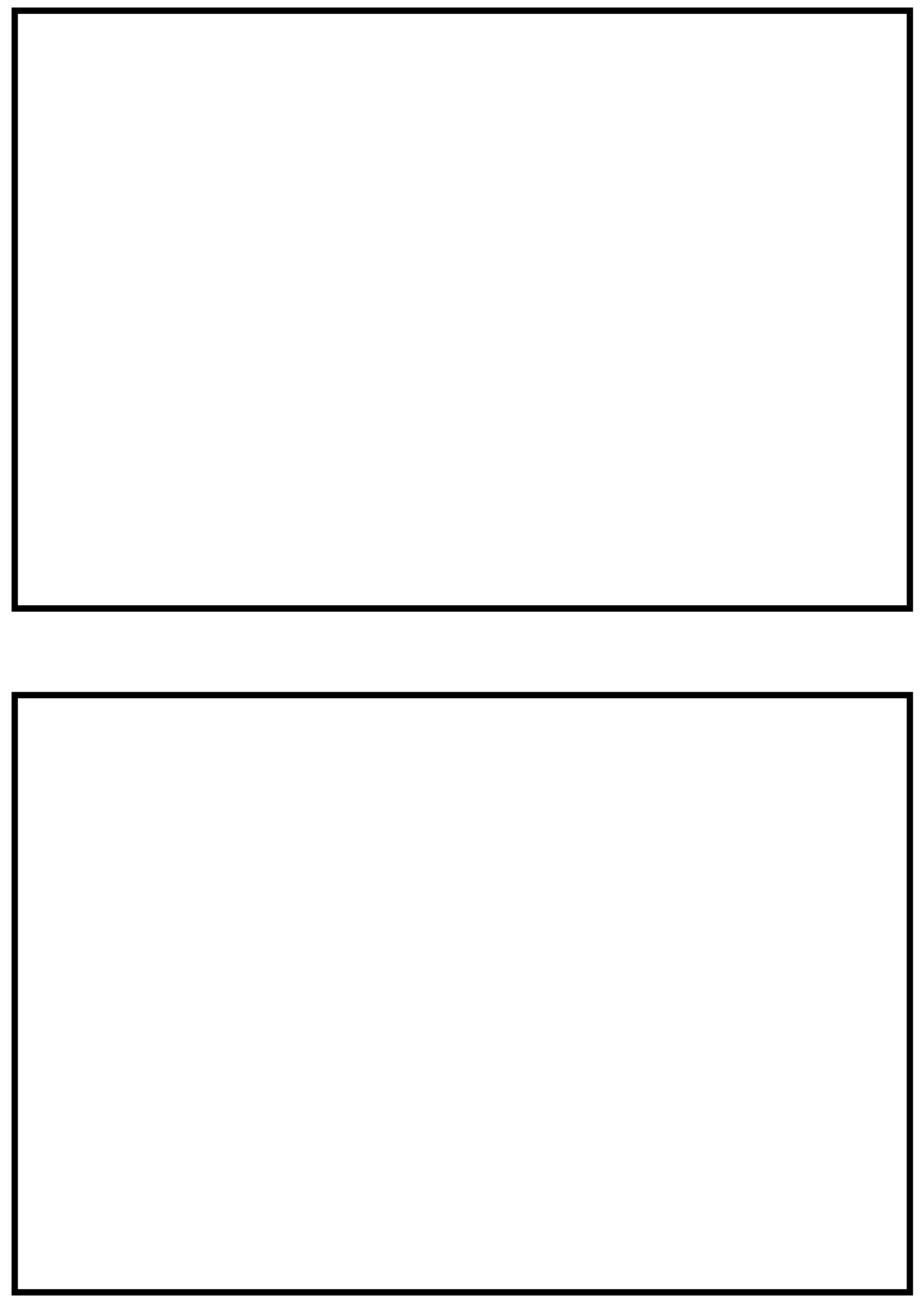

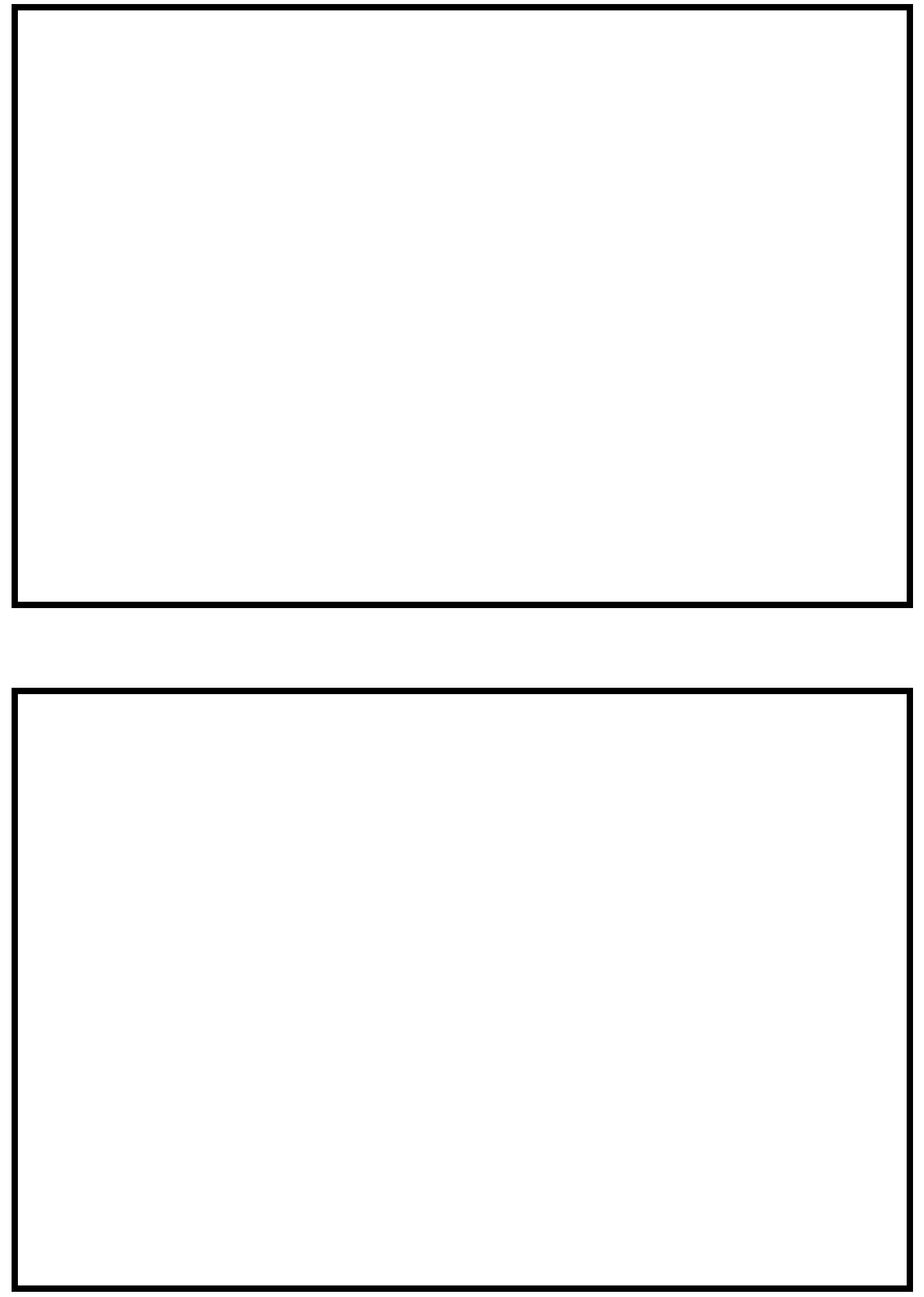


\section{LEVEL II SUMMARY}

\begin{tabular}{llllll} 
Structure Number & CLARTH00100025 & Stream & \multicolumn{3}{c}{ Clarendon River } \\
& Road & TH10 & & \\
County & Rutland & Ristrict &
\end{tabular}

\section{Description of Bridge}

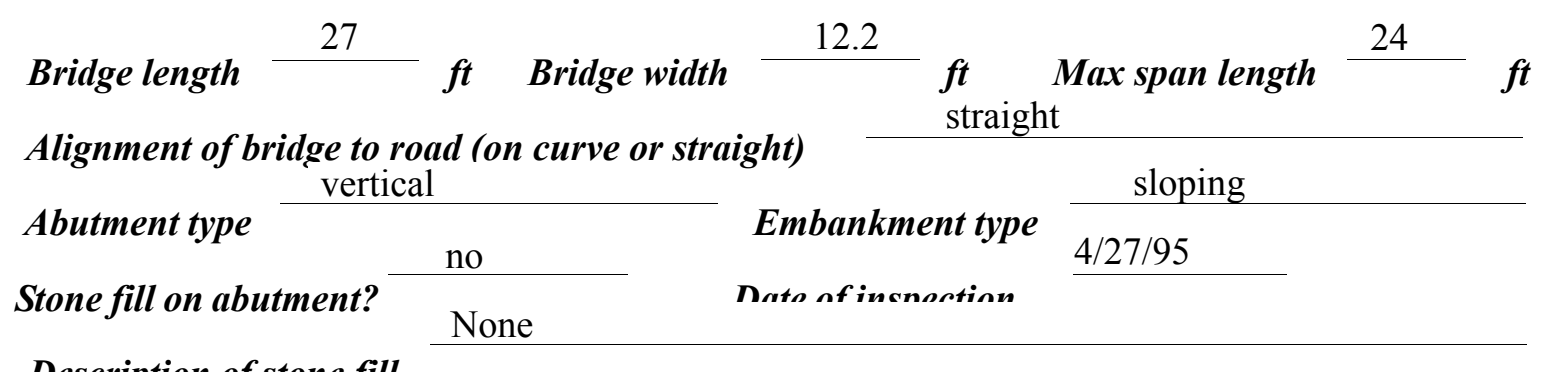

Left abutment is stone. Right abutment is concrete with one wing wall on the upstream right bank

Is bridge skewed to flood flow according to $\mathrm{Y} \quad$ survey?
Moderate. The skew.angle of the stream to the bridge is up to 10 degrees. Opening skew to
roadway is 0 degrees and the left abutment is attacked at approx. 15 degrees

Debris accumulation on bridge at time of Level I or Level II site visit:

\section{Date of incnortion $04 / 27 / 95$ \\ Percent of rhamnal blocked inorizontatly}

Level I

same
Percent of annel blocked verticatty

\section{Level II}

Low, due to lack of woody vegetation upstream of the structure

Bank-full flow at this site goes through a strong meander just upstream of the bridge and Potential for debris

attacks the right bank at the upstream face of the bridge; flow then attacks the left abutment Doscriho any foaturos noar ar at tho hridoo that mav, affort flow, (includo ahsorvation datol within the bridge opening. 


\section{Description of the Geomorphic Setting}

General topography The bridge is in a $2000 \mathrm{ft}$-wide, flat valley approx. $1000 \mathrm{ft}$ DS of a major constriction. The roadway is the highest land feature in the bridge vicinity.

Geomorphic conditions at bridge site: downstream (DS), upstream (US)

Date of inspection $\quad 04 / 27 / 95$

DS left: $\quad$ mostly flat, wide overbank vegetated with field grasses.

DS right: $\quad$ mostly flat, wide overbank vegetated with field grasses.

US left: $\quad$ mostly flat, wide overbank vegetated with field grasses.

US right: $\quad$ mostly flat, wide overbank vegetated with field grasses.

\section{Description of the Channel}

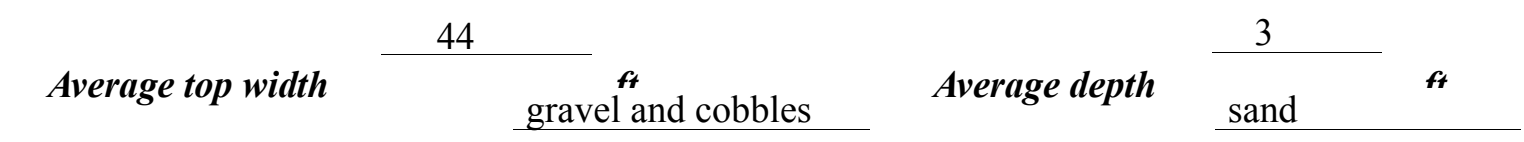

Predominant bed material

Bank material

sinuous, with large

flood plains. It is alluvial and laterally unstable

$4 / 27 / 95$

Vegetative co 1 field grasses

DS left: $\quad$ field grasses

DS right: field grasses

US left: $\quad$ field grasses

US right:

Do banks appear stable? 07/27/95--Banks are reported to be eroded by means of moderate to

heavy fluvial processes. The USRB is eroded heavily due to flow impact; the USRB more stable
date of observatton. but is eroded in places; the DSLB has moderate fluvial erosion and DSRB has light fluvial erosion.

obstructions; a shallow riffle-dam is several feet upstream of bridge face Describe any obstructions in channel and date of observation. 


\section{Hydrology}

Drainage area $\frac{19.3}{\mathrm{mi}^{2}}$

Percentage of drainage area in physiographic provinces: (approximate)

Physiographic province/section

New England Province/Taconic Section
Percent of drainage area 100

Is drainage area considered rural or urban? Rural $\quad$ Describe any significant
urbanization:

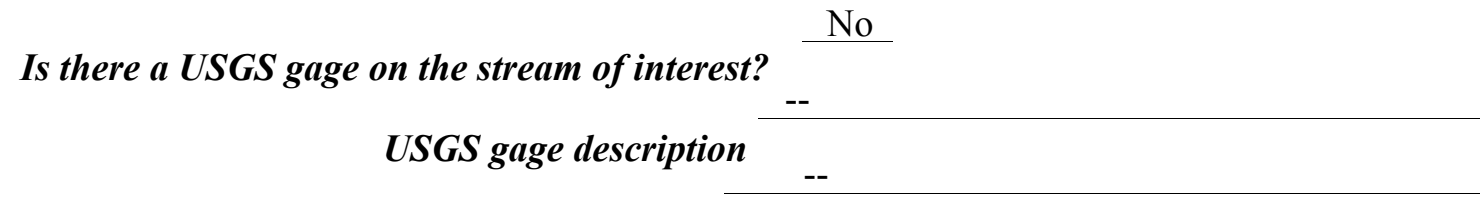

USGS gage number

Gage drainage area $\quad \boldsymbol{m i}^{2} \quad$ Yes

Is there a lake/p There are several major swamp areas in the drainage area. Each is controlled by a natural constriction in the channel. These account for up to 13 percent of the area; areas that are not swamp or lowland are steep uplands, which rise out of the low areas. 1,440

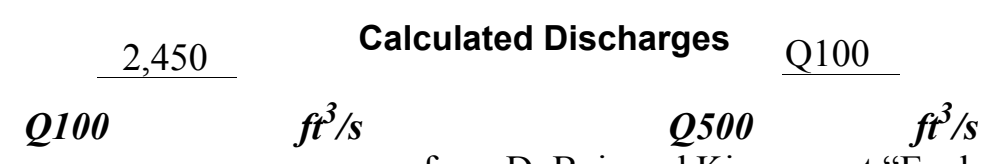
from DuBois and King report "Evaluation of the

Bridge No. 25 on Town Highway \#10 Village of Chippenhook, Clarendon, Vermont; Alignment and Bridge Type Study -- approved by VTAOT (DuBois and King, Inc, 1995); Q500 determined by multiplying Q100 by 1.7 (Richardson and others, 1983). These values were considered reasonable compared to values from empirical methods (Benson, 1962; Johnson and Tasker, 1974; FHWA, 1983; Potter, 1957a\&b; Talbot, 1887) which ranged from 335 to $>4000$ cfs for the 100-yr flood. 


\section{Description of the Water-Surface Profile Model (WSPRO) Analysis}

Datum for WSPRO analysis (USGS survey, sea level, VTAOT plans)

USGS survey

Datum tie between USGS survey and VTAOT plans

N/A

Description of reference marks used to determine USGS datum. $\quad$ RM1 is a spike in a pole at the intersection of TH5 and TH10. The pole is in the DS right-bank corner of the intersection; the arbitrary elevation is 507.910 feet.

\section{Cross-Sections Used in WSPRO Analysis}

\begin{tabular}{|c|c|c|c|}
\hline${ }^{1}$ Cross-section & $\begin{array}{c}\text { Section } \\
\text { Reference } \\
\text { Distance } \\
\text { (SRD) in feet }\end{array}$ & $\begin{array}{c}{ }^{2} \text { Cross-section } \\
\text { development }\end{array}$ & Comments \\
\hline EXITX & -25 & 1 & Exit section \\
\hline FULLV & 0 & 2 & $\begin{array}{l}\text { Downstream Full-valley } \\
\text { section (Templated from } \\
\text { EXITX) }\end{array}$ \\
\hline BRIDG & 0 & 1 & Bridge section \\
\hline RDWAY & 6 & 1 & Road Grade section \\
\hline APPRO & 43 & 1 & Approach section \\
\hline
\end{tabular}

${ }^{1}$ For location of cross-sections see plan-view sketch included with Level I field form, Appendix E. For more detail on how cross-sections were developed see WSPRO input file. 


\section{Data and Assumptions Used in WSPRO Model}

Hydraulic analyses of the reach were done by use of the Federal Highway Administration's WSPRO step-backwater computer program (Shearman and others, 1986, and Shearman, 1990). The analyses reported herein reflect conditions existing at the site at the time of the study. Furthermore, in the development of the model it was necessary to assume no accumulation of debris or ice at the site. Results of the hydraulic model are presented in the Bridge Hydraulic Summary, Appendix B, and figure 7.

Channel roughness factors (Manning's " $n$ ") used in the hydraulic model were estimated using field inspections at each cross section following the general guidelines described by Arcement, Jr. and Schneider (1989). Final adjustments to the values were made during the modelling of the reach. Channel " $n$ " values for the reach ranged from 0.035 to 0.043 , and overbank " $n$ " values ranged from 0.032 to 0.033 .

Normal depth at the exit section (EXITX) was assumed as the starting water surface. This depth was computed by use of the slope-conveyance method outlined in the user's manual for WSPRO (Shearman, 1990). The slope used was $0.00653 \mathrm{ft} / \mathrm{ft}$ which was calculated from water surface points downstream of the bridge.

The surveyed approach section (APPRO) was approximately one bridge length upstream of the upstream bridge face as recommended by Shearman and others (1986). This approach also provides a consistent method for determining scour variables.

The roadway was overtopped in both the 100- and 500-year models. The incipient roadway overtopping discharge was $556 \mathrm{cfs}$. 


\section{Bridge Hydraulics Summary}

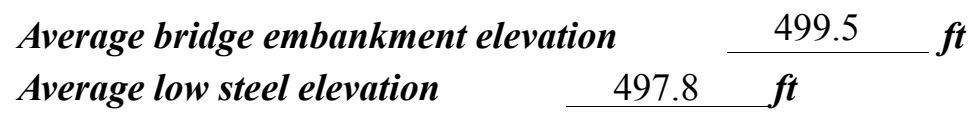

$$
\text { 100-year discharge } \quad 1,440 \quad \mathrm{ft}^{3} / \mathrm{s}
$$

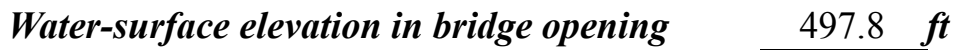

Road overtopping? ___ Y Discharge over road _ $605, \ldots$

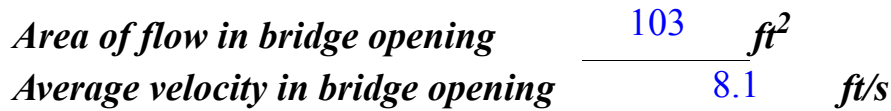

$\begin{array}{lll}\text { Maximum WSPRO tube velocity at bridge } & 9.7 \mathrm{ft} / \mathrm{s}\end{array}$

Water-surface elevation at Approach section with bridge 499.8

Water-surface elevation at Approach section without bridge $\quad \overline{496.8}$

Amount of backwater caused by bridge $\quad 3.0$ it

500-year discharge $\quad 2,450 \quad \mathrm{ft}^{3} / \mathrm{s}$

Water-surface elevation in bridge opening $\quad 497.8 \mathrm{ft}$

Road overtopping? ___ Y Discharge over road _ $\quad 1,570, \ldots$

$\begin{array}{llll}\text { Area of flow in bridge opening } & 103 & \boldsymbol{f t}^{2} & \\ \text { Average velocity in bridge opening } & & 8.7 \quad \mathbf{f t} / \mathbf{s}\end{array}$

Maximum WSPRO tube velocity at bridge $\quad 10.4$ 's

Water-surface elevation at Approach section with bridge 500.4

Water-surface elevation at Approach section without bridge $\quad 497.3$

Amount of backwater caused by bridge 3.1 .

Incipient overtopping discharge $\quad 556 \quad \mathrm{ft}^{3} / \mathrm{s}$

Water-surface elevation in bridge opening $497.8 \quad t$

Area of flow in bridge opening $\quad 103 \quad \mathrm{ft}^{2}$

$\begin{array}{lll}\text { Average velocity in bridge opening } & 5.3 \mathrm{ft} / \mathrm{s}\end{array}$

Maximum WSPRO tube velocity at bridge $\quad 6.5 \mathrm{ft} / \mathrm{s}$

Water-surface elevation at Approach section with bridge

Water-surface elevation at Approach section without bridge

498.4

Amount of backwater caused by bridge $\quad 2.2$, $t$

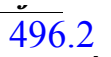




\section{Scour Analysis Summary}

\section{Special Conditions or Assumptions Made in Scour Analysis}

Scour depths were computed using the general guidelines described in Hydraulic Engineering Circular 18 (Richardson and others, 1993). Scour depths were calculated assuming an infinite depth of erosive material and a homogeneous particle-size distribution. The results of the scour analysis are presented in tables 1 and 2 and a graph of the scour depths is presented in figure 8.

Contraction scour was computed by use of the Chang pressure-flow scour equation (Richardson and others, 1995, p. 145-146). For each of the modelled discharges, there was orifice flow at the bridge. Contraction scour at bridges with orifice flow is best estimated by use of the Chang pressure-flow scour equation (oral communication, J. Sterling Jones, October 4, 1996). The results of Laursen's clear-water contraction scour equation (Richardson and others, 1995, p. 32, equation 20) were also computed and can be found in appendix F.

Abutment scour was computed by use of the HIRE equation (Richardson and others, 1993, p. 49, equation 29). Variables for the HIRE equation include the Froude number of the flow approaching the embankments, the length of the embankment blocking flow, and the depth of flow approaching the embankment less any roadway overtopping. The HIRE equation is recommended when the length to depth ratio of the embankment blocking flow exceeds 25 . 


\section{Scour Results}

\section{0-yr discharge 500-yr discharge}

Contraction scour:

(Scour depths in feet)

Main channel

Live-bed scour

Clear-water scour

Depth to armoring

Left overbank

Right overbank

Local scour:

Abutment scour

Left abutment

8.5

8.5

5.7

8.9-

$10.6-$

$5.8-$

Right abutment

Pier scour

Pier 1

Pier 2

Pier 3

\section{Abutments:}

Left abutment

Right abutment

Piers:

Pier 1

Pier 2

overtopping discharge 


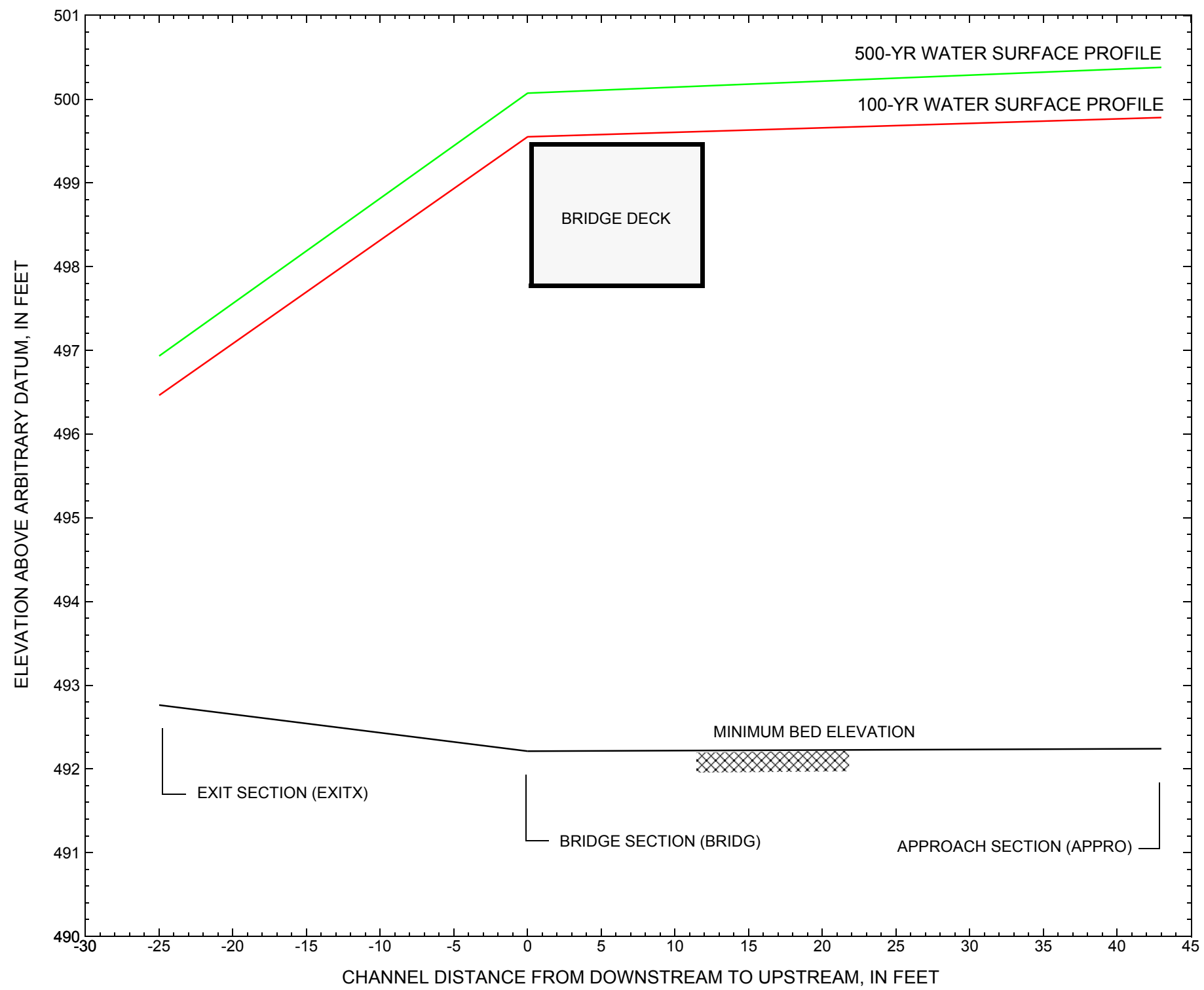

Figure 7. Water-surface profiles for the 100- and 500-yr discharges at structure CLARTH00100025 on town highway 10, crossing the Clarendon River, Clarendon, Vermont. 


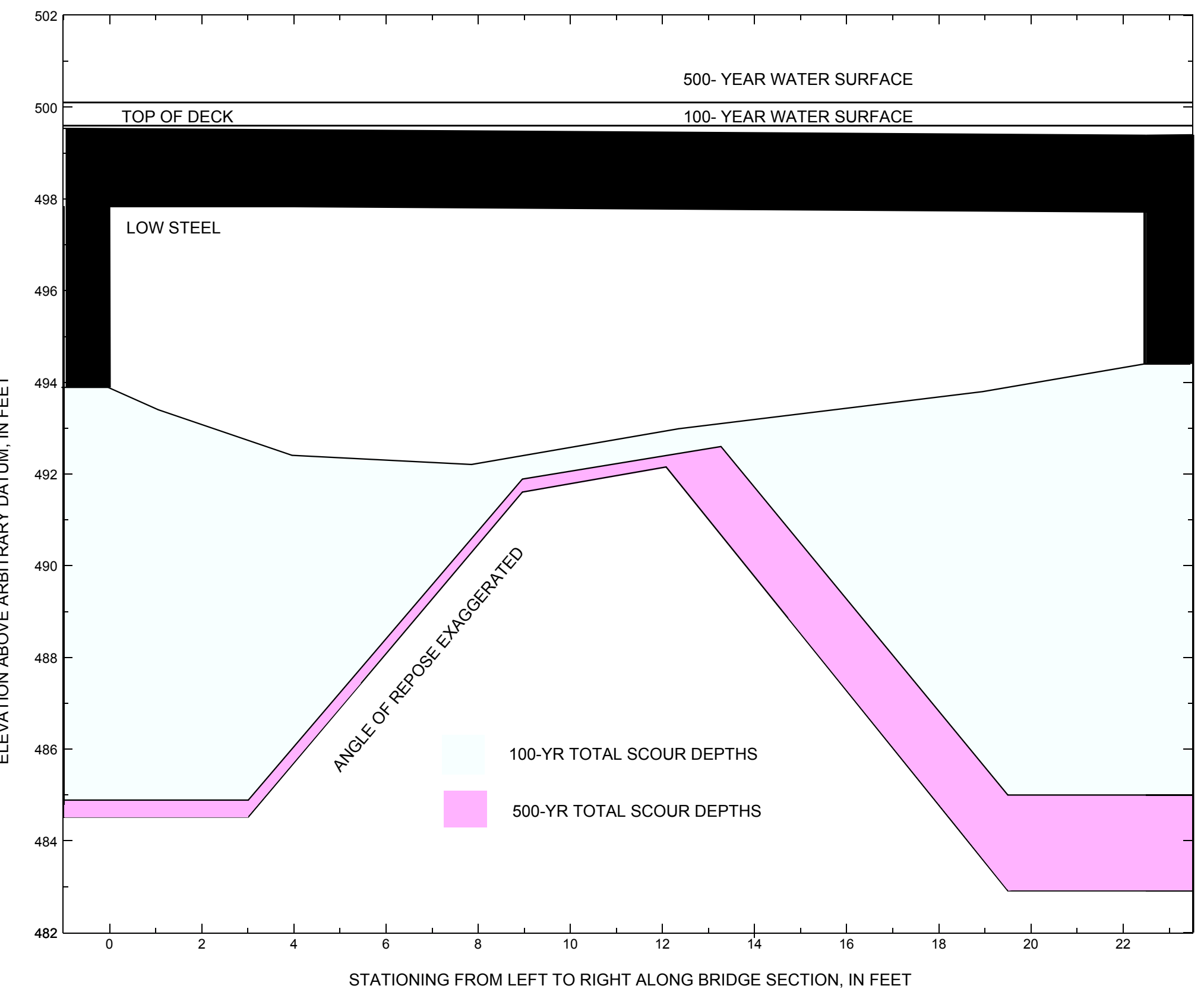

Figure 8. Scour elevations for the 100-yr and 500-yr discharges at structure CLARTH00100025 on town highway 10, crossing the Clarendon River, Clarendon, Vermont. 
Table 1. Remaining footing/pile depth at abutments for the 100-year discharge at structure CLARTH00100025 on Town Highway 10, crossing the Clarendon River, Clarendon, Vermont.

[VTAOT, Vermont Agency of Transportation; --,no data]

\begin{tabular}{|c|c|c|c|c|c|c|c|c|c|c|c|}
\hline Description & Station $^{1}$ & $\begin{array}{l}\text { VTAOT } \\
\text { minimum } \\
\text { low-chord } \\
\text { elevation } \\
\text { (feet) }\end{array}$ & $\begin{array}{l}\text { Surveyed } \\
\text { minimum } \\
\text { low-chord } \\
\text { elevation } \\
\text { (feet) }\end{array}$ & $\begin{array}{l}\text { Bottom of } \\
\text { footing } \\
\text { elevation } \\
\text { (feet) }\end{array}$ & $\begin{array}{l}\text { Channel } \\
\text { elevation at } \\
\text { abutment/ } \\
\text { pier }^{2} \\
\text { (feet) }\end{array}$ & $\begin{array}{l}\text { Contraction } \\
\text { scour depth } \\
\text { (feet) }\end{array}$ & $\begin{array}{l}\text { Abutment } \\
\text { scour } \\
\text { depth } \\
\text { (feet) }\end{array}$ & $\begin{array}{l}\text { Pier } \\
\text { scour } \\
\text { depth } \\
\text { (feet) }\end{array}$ & $\begin{array}{l}\text { Depth of } \\
\text { total scour } \\
\text { (feet) }\end{array}$ & $\begin{array}{c}\text { Elevation of } \\
\text { scour }^{2} \\
\text { (feet) }\end{array}$ & $\begin{array}{c}\text { Remaining } \\
\text { footing/pile } \\
\text { depth } \\
\text { (feet) }\end{array}$ \\
\hline \multicolumn{12}{|c|}{100 -yr. discharge is 1,440 cubic-feet per second } \\
\hline Left abutment & -1.1 & -- & 497.8 & -- & 493.9 & 0.5 & 8.5 & -- & 9.0 & 484.9 & -- \\
\hline Right abutment & 21.4 & -- & 497.7 & -- & 494.4 & 0.5 & 8.9 & -- & 9.4 & 485.0 & -- \\
\hline
\end{tabular}

1. Measured along the face of the most constricting side of the bridge.

2. Arbitrary datum for this study.

Table 2. Remaining footing/pile depth at abutments for the 500-year discharge at structure CLARTH00100025 on Town Highway 10, crossing the Clarendon River, Clarendon, Vermont.

[VTAOT, Vermont Agency of Transportation; --, no data]

\begin{tabular}{|c|c|c|c|c|c|c|c|c|c|c|c|}
\hline Description & Station $^{1}$ & $\begin{array}{l}\text { VTAOT } \\
\text { minimum } \\
\text { low-chord } \\
\text { elevation } \\
\text { (feet) }\end{array}$ & $\begin{array}{l}\text { Surveyed } \\
\text { minimum } \\
\text { low-chord } \\
\text { elevation } \\
\text { (feet) }\end{array}$ & $\begin{array}{l}\text { Bottom of } \\
\text { footing } \\
\text { elevation } \\
\text { (feet) }\end{array}$ & $\begin{array}{c}\text { Channel } \\
\text { elevation at } \\
\text { abutment/ } \\
\text { pier }^{2} \\
\text { (feet) }\end{array}$ & $\begin{array}{l}\text { Contraction } \\
\text { scour depth } \\
\text { (feet) }\end{array}$ & $\begin{array}{l}\text { Abutment } \\
\text { scour } \\
\text { depth } \\
\text { (feet) }\end{array}$ & $\begin{array}{l}\text { Pier } \\
\text { scour } \\
\text { depth } \\
\text { (feet) }\end{array}$ & $\begin{array}{l}\text { Depth of } \\
\text { total scour } \\
\text { (feet) }\end{array}$ & $\begin{array}{c}\text { Elevation of } \\
\text { scour }^{2} \\
\text { (feet) }\end{array}$ & $\begin{array}{c}\text { Remaining } \\
\text { footing/pile } \\
\text { depth } \\
\text { (feet) }\end{array}$ \\
\hline \multicolumn{12}{|c|}{500 -yr. discharge is 2,450 cubic-feet per second } \\
\hline Left abutment & -1.1 & -- & 497.8 & -- & 493.9 & 0.8 & 8.5 & -- & 9.3 & 484.6 & -- \\
\hline Right abutment & 21.4 & -- & 497.7 & -- & 494.4 & 0.8 & 10.6 & -- & 11.4 & 483.0 & -- \\
\hline
\end{tabular}

1. Measured along the face of the most constricting side of the bridge.

2. Arbitrary datum for this study. 


\section{SELECTED REFERENCES}

Arcement, G.J., Jr., and Schneider, V.R., 1989, Guide for selecting Manning's roughness coefficients for natural channels and flood plains: U.S. Geological Survey Water-Supply Paper 2339, 38 p.

Barnes, H.H., Jr., 1967, Roughness characteristics of natural channels: U.S. Geological Survey Water-Supply Paper 1849,213 p.

Benson, M. A., 1962, Factors Influencing the Occurrence of Floods in a Humid Region of Diverse Terrain: U.S. Geological Survey WaterSupply Paper 1580-B, 64 p.

Brown, S.A. and Clyde, E.S., 1989, Design of riprap revetment: Federal Highway Administration Hydraulic Engineering Circular No. 11, Publication FHWA-IP-89-016, 156 p.

DuBois and King, Inc., 1995, Evaluation of the Bridge No. 25 on Town Highway \#10 Village of Chippenhook, Clarendon, Vermont; Alignment and Bridge Type Study, 19 p.

Federal Highway Administration, 1983, Runoff estimates for small watersheds and development of sound design: Federal Highway Administration Report FHWA-RD-77-158

Froehlich, D.C., 1989, Local scour at bridge abutments in Ports, M.A., ed., Hydraulic Engineering--Proceedings of the 1989 National Conference on Hydraulic Engineering: New York, American Society of Civil Engineers, p. 13-18.

Hayes, D.C.,1993, Site selection and collection of bridge-scour data in Delaware, Maryland, and Virginia: U.S. Geological Survey WaterResources Investigation Report 93-4017, 23 p.

Interagency Advisory Committee on Water Data, 1982, Guidelines for determining flood flow frequency: U.S. Geological Survey, Bulletin 17B of the Hydrology Subcommittee, 190 p.

Johnson, C.G. and Tasker, G.D.,1974, Progress report on flood magnitude and frequency of Vermont streams: U.S. Geological Survey OpenFile Report 74-130, 37 p.

Lagasse, P.F., Schall, J.D., Johnson, F., Richardson, E.V., Chang, F., 1995, Stream Stability at Highway Structures: Federal Highway Administration Hydraulic Engineering Circular No. 20, Publication FHWA-IP-90-014, 144 p.

Laursen, E.M., 1960, Scour at bridge crossings: Journal of the Hydraulics Division, American Society of Civil Engineers, v. 86, no. HY2, p. 39-53.

Potter, W. D., 1957a, Peak rates of runoff in the Adirondack, White Mountains, and Maine woods area, Bureau of Public Roads

Potter, W. D., 1957b, Peak rates of runoff in the New England Hill and Lowland area, Bureau of Public Roads

Richardson, E.V. and Davis, S.R., 1995, Evaluating scour at bridges: Federal Highway Administration Hydraulic Engineering Circular No. 18, Publication FHWA-IP-90-017, 204 p.

Richardson, E.V., Simons, D.B., and Julien, P.Y., 1990, Highways in the river environment: Federal Highway Administration Publication FHWA-HI-90-016.

Ritter, D.F., 1984, Process Geomorphology: W.C. Brown Co., Debuque, Iowa, 603 p.

Shearman, J.O., 1990, User's manual for WSPRO--a computer model for water surface profile computations: Federal Highway Administration Publication FHWA-IP-89-027, 187 p.

Shearman, J.O., Kirby, W.H., Schneider, V.R., and Flippo, H.N., 1986, Bridge waterways analysis model; research report: Federal Highway Administration Publication FHWA-RD-86-108, 112 p.

Talbot, A.N., 1887, The determination of water-way for bridges and culverts.

U.S. Department of Transportation, 1993, Stream stability and scour at highway bridges, Participant Workbook: Federal Highway Administration Publication FHWA HI-91-011.

U.S. Geological Survey, 1964, West Rutland, Vermont 7.5 Minute Series quadrangle map: U.S. Geological Survey Topographic Maps, Photorevised 1972, Scale 1:24,000. 


\section{APPENDIX A: \\ WSPRO INPUT FILE}




\section{WSPRO INPUT FILE}

GR

GR

GR

GR

GR

GR

$\mathrm{N}$

SA

XS

$\mathrm{BR}$

GR

GR

GR

$\mathrm{N}$

CD

*

$\mathrm{XR}$

GR

GR

GR

GR

AS

GR

GR

GR

GR

GR

GR

$\mathrm{N}$

SA

\section{*}

HP 1 BRIDG

HP 2 BRIDG

HP 2 RDWAY

HP 1 APPRO

HP 2 APPRO

*

HP 1 BRIDG HP 2 BRIDG

HP 2 RDWAY

HP 1 APPRO

HP 2 APPRO

*

HP 1 BRIDG

RDWAY

U.S. GEOLOGICAL SURVEY WSPRO INPUT FILE Clar025.wsp CREATED ON 17-MAY-95 FOR BRIDGE clarth00010025 USING FILE clar025.dca bridge clar025, West Rutland, VT quadrangle

$\begin{array}{lllllllllllllllllllll}6 & 29 & 30 & 552 & 553 & 551 & 5 & 16 & 17 & 13 & 3 & * & 15 & 14 & 23 & 21 & 11 & 12 & 4 & 7 & 3\end{array}$

$\begin{array}{llc}1440 & 2450 & 556 \\ 0.00653 & 0.00653 & 0.00653\end{array}$

$\operatorname{EXITX} \quad-25$

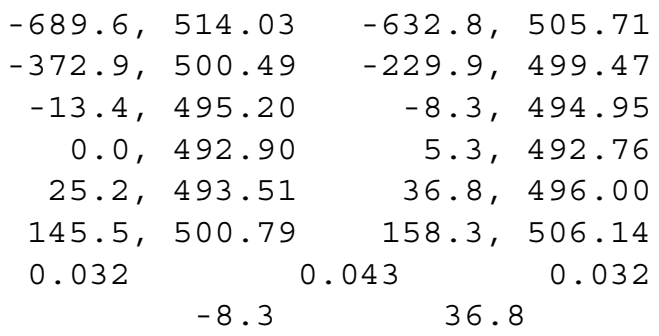

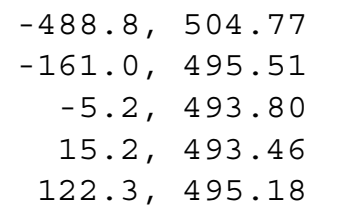

$-394.9,500.65$

$-28.8,495.80$

$-3.9,493.36$

$22.1,493.25$

$135.8,496.07$

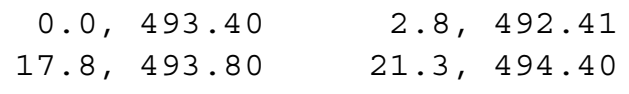

$$
\begin{array}{rl}
-1.1,497.84 & -0.3,493.89 \\
6.7,492.21 & 11.2,492.99 \\
21.4,497.70 & -1.1,497.84 \\
0.035 & \\
2122.3498 .3 * 0.0
\end{array}
$$

$$
\begin{aligned}
& -661.9,510.77 \\
& -188.3,499.75 \\
& 29.0,499.53 \\
& 118.3,498.70
\end{aligned}
$$

$\begin{array}{rr}2 & \\ -584.2, & 506.74 \\ -56.9, & 498.39 \\ 31.7, & 499.39 \\ 168.1, & 499.95\end{array}$

$$
-4
$$

$$
2.2
$$$$
0.043
$$

42.1$$
\begin{array}{rr}
-459.0, & 504.24 \\
-2.4, & 499.53 \\
46.2, & 499.13 \\
257.0, & 504.95
\end{array}
$$

$-298.4,501.85$

$0.0,499.53$

$75.0,498.83$

$-525.8,505.19$

$-429.6,502.83$

$-38.2,496.20$

$3.7,493.79$

$40.3,492.40$

$130.3,495.85$

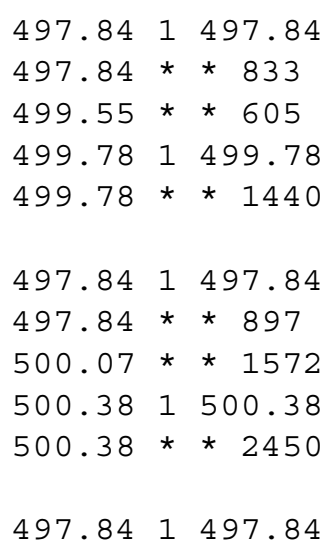




\section{APPENDIX B: \\ WSPRO OUTPUT FILE}




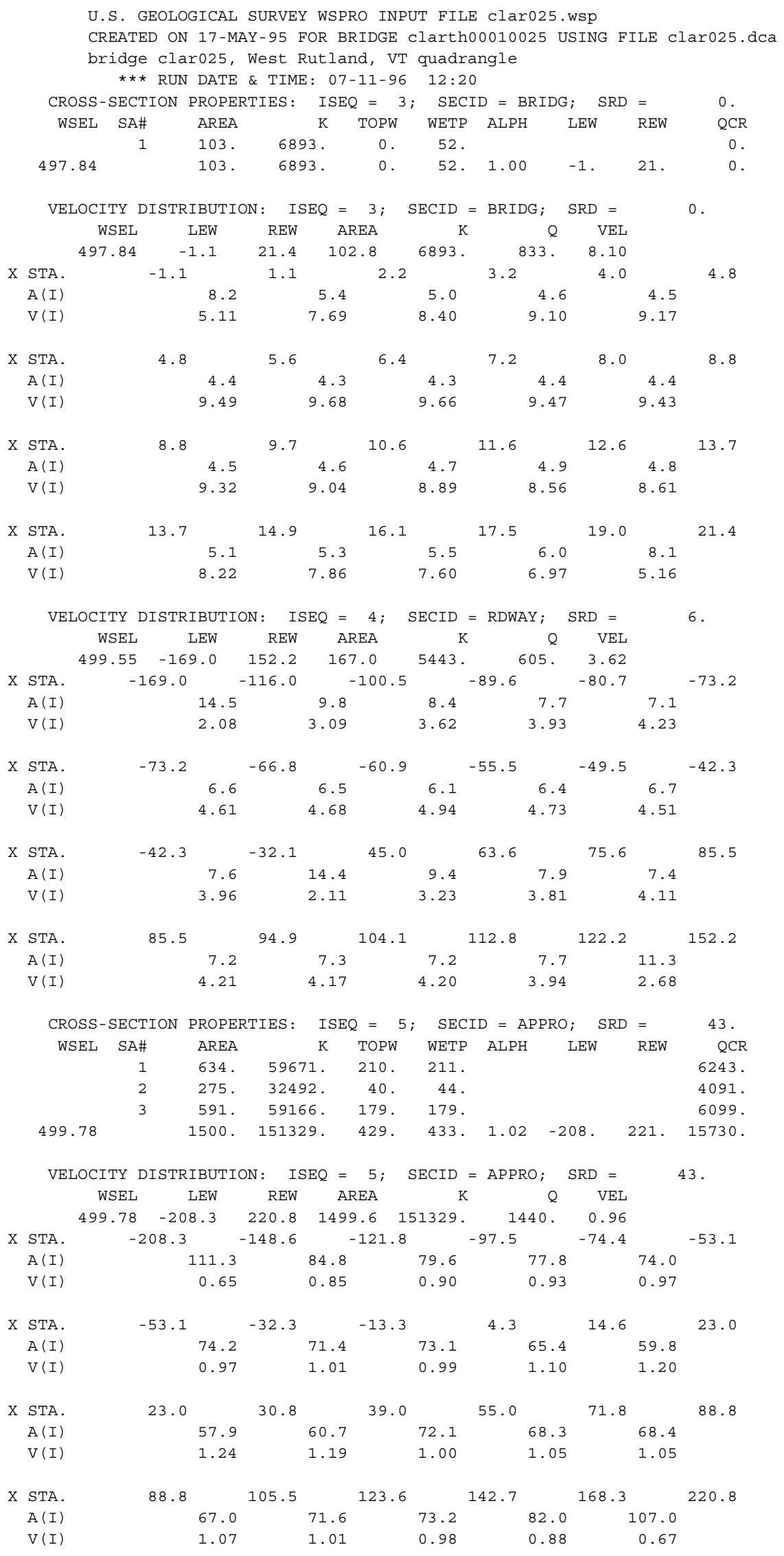


WSPRO OUTPUT FILE (continued)

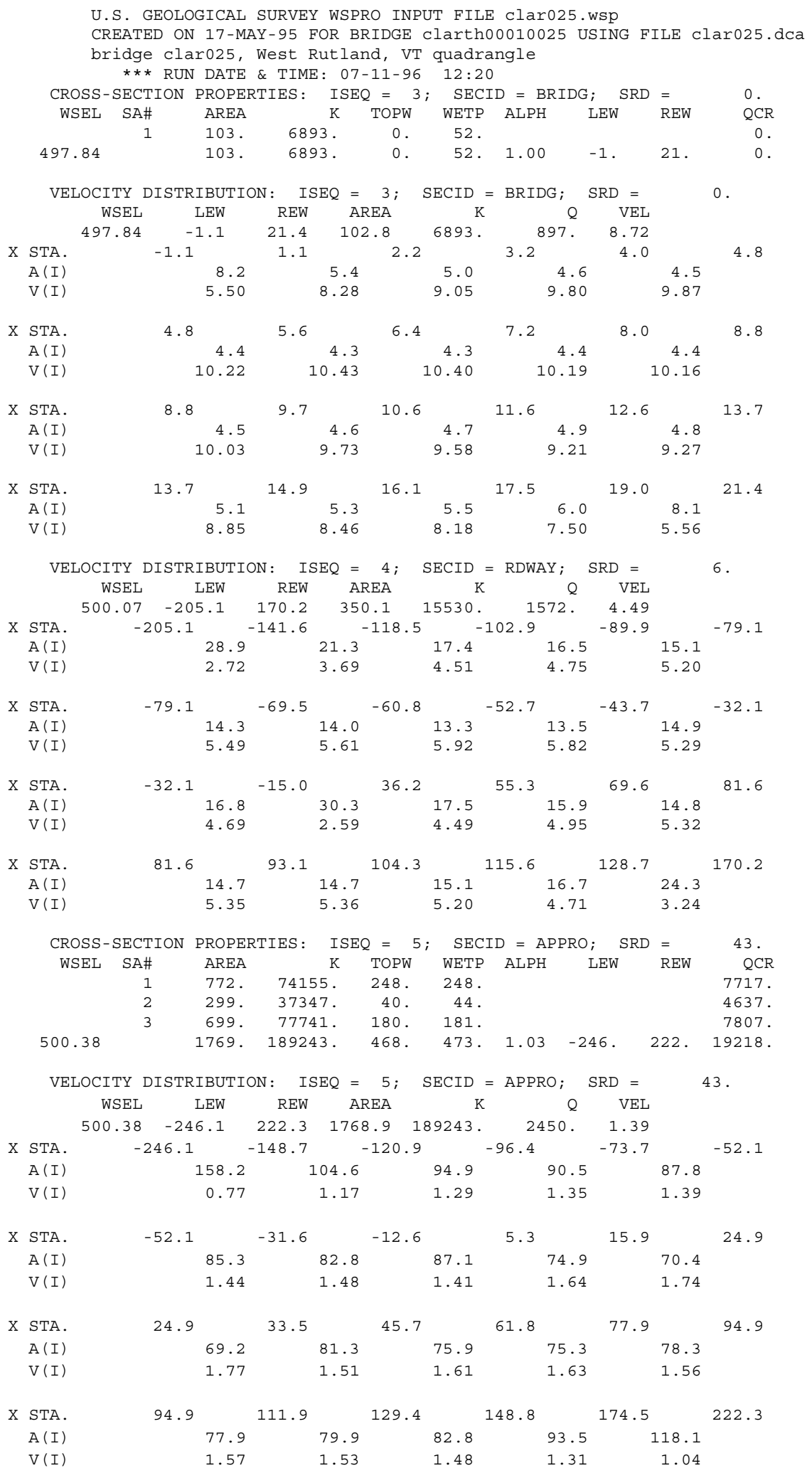


WSPRO OUTPUT FILE (continued)

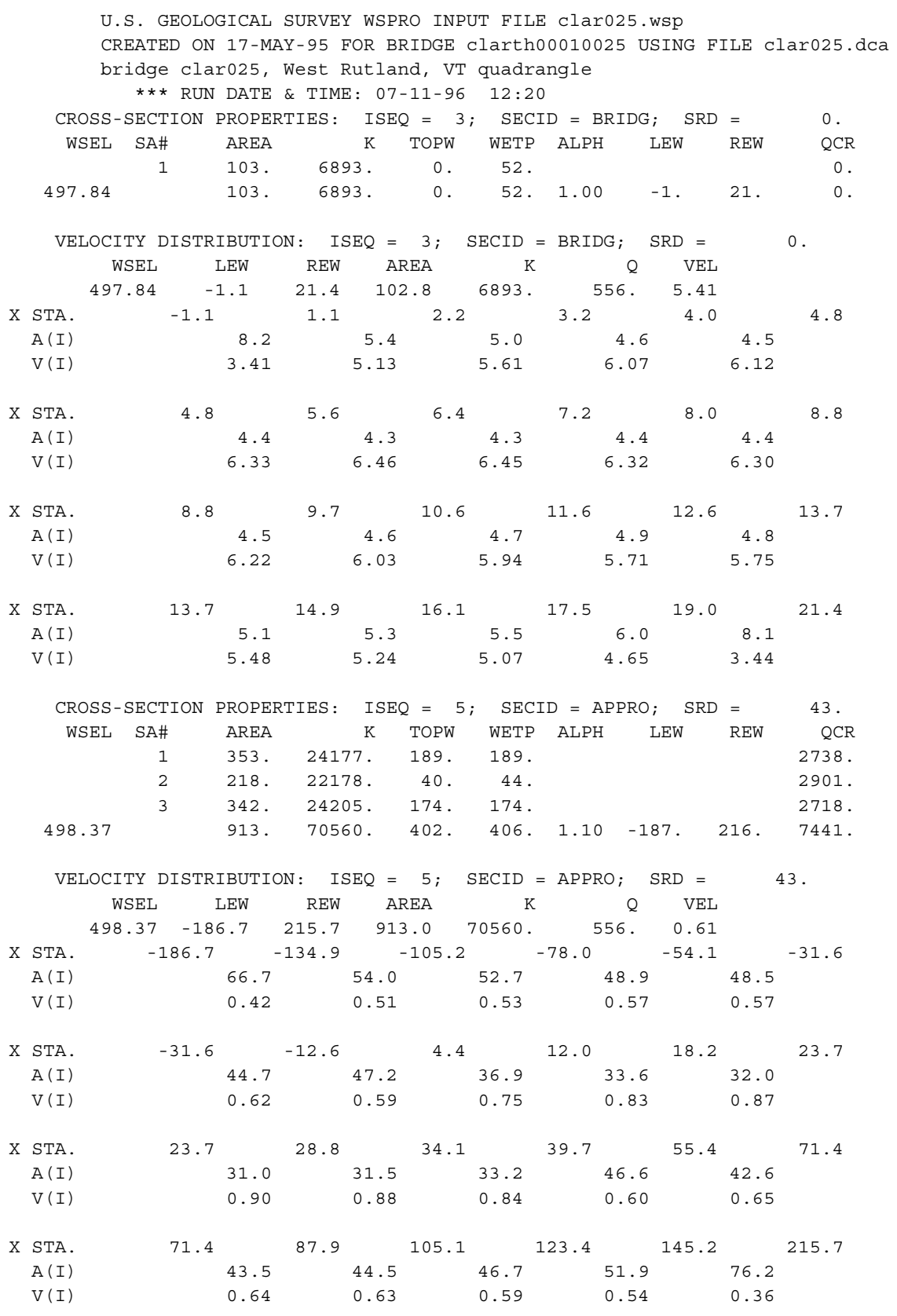


WSPRO OUTPUT FILE (continued)

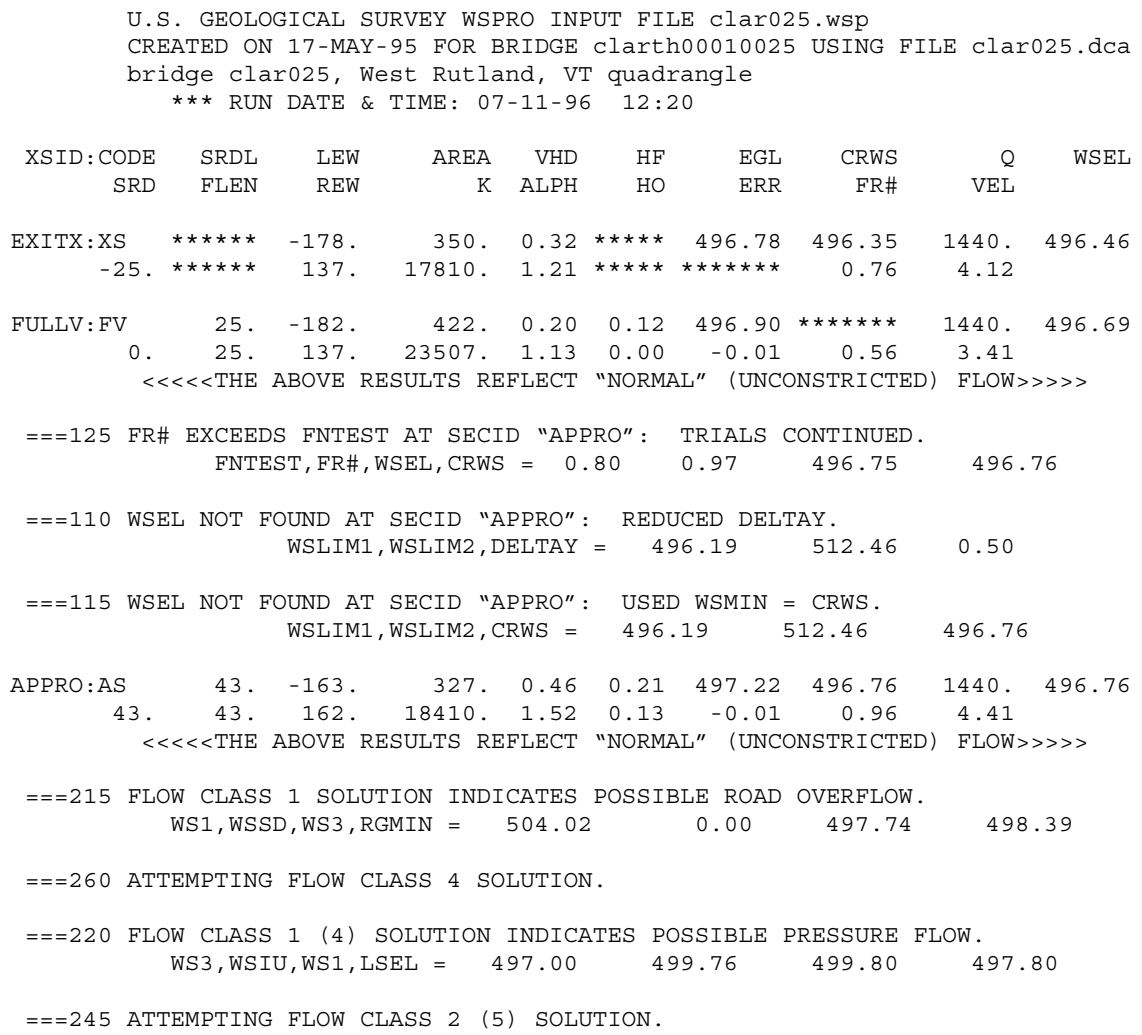


WSPRO OUTPUT FILE (continued)

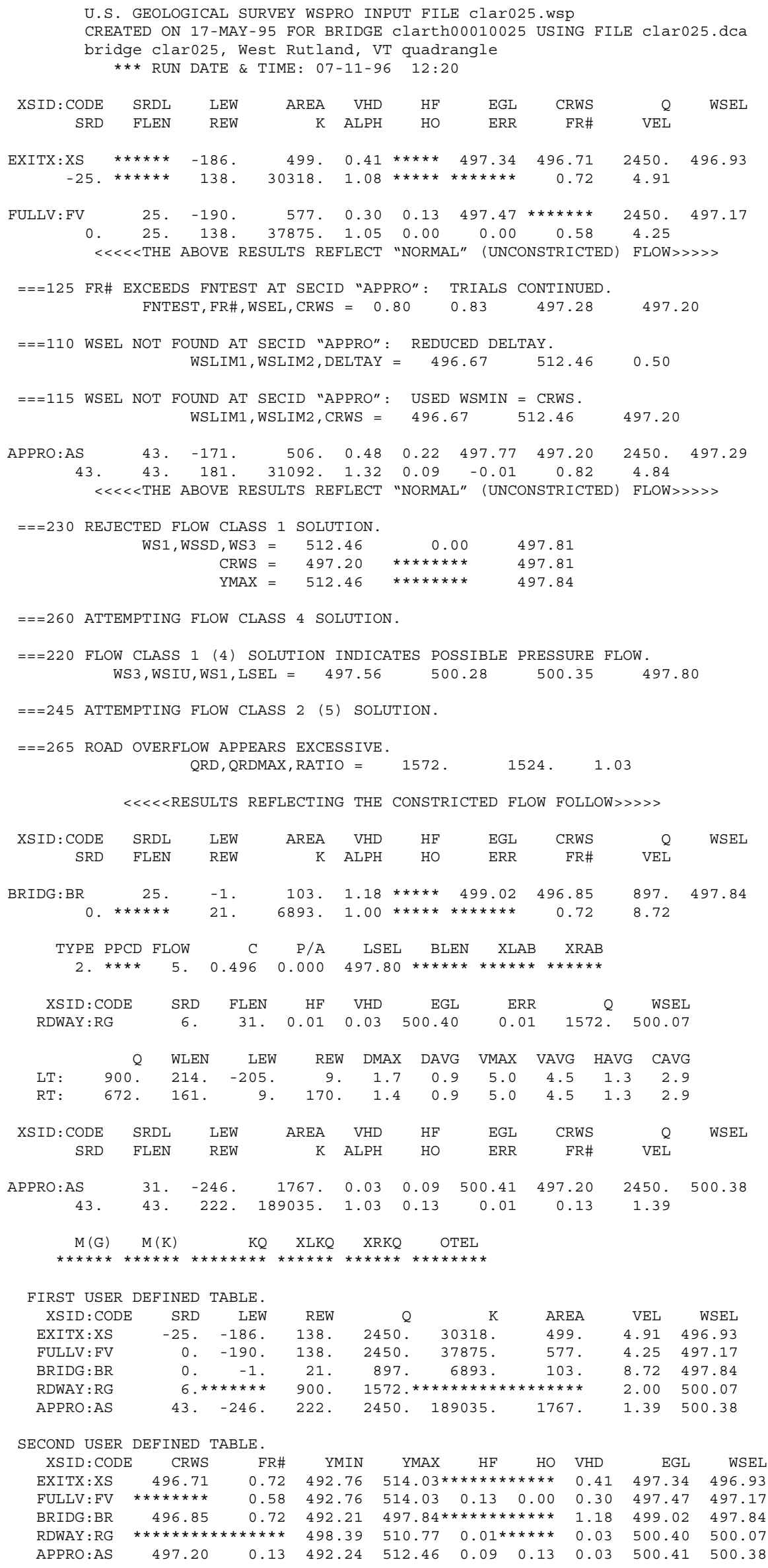


WSPRO OUTPUT FILE (continued)

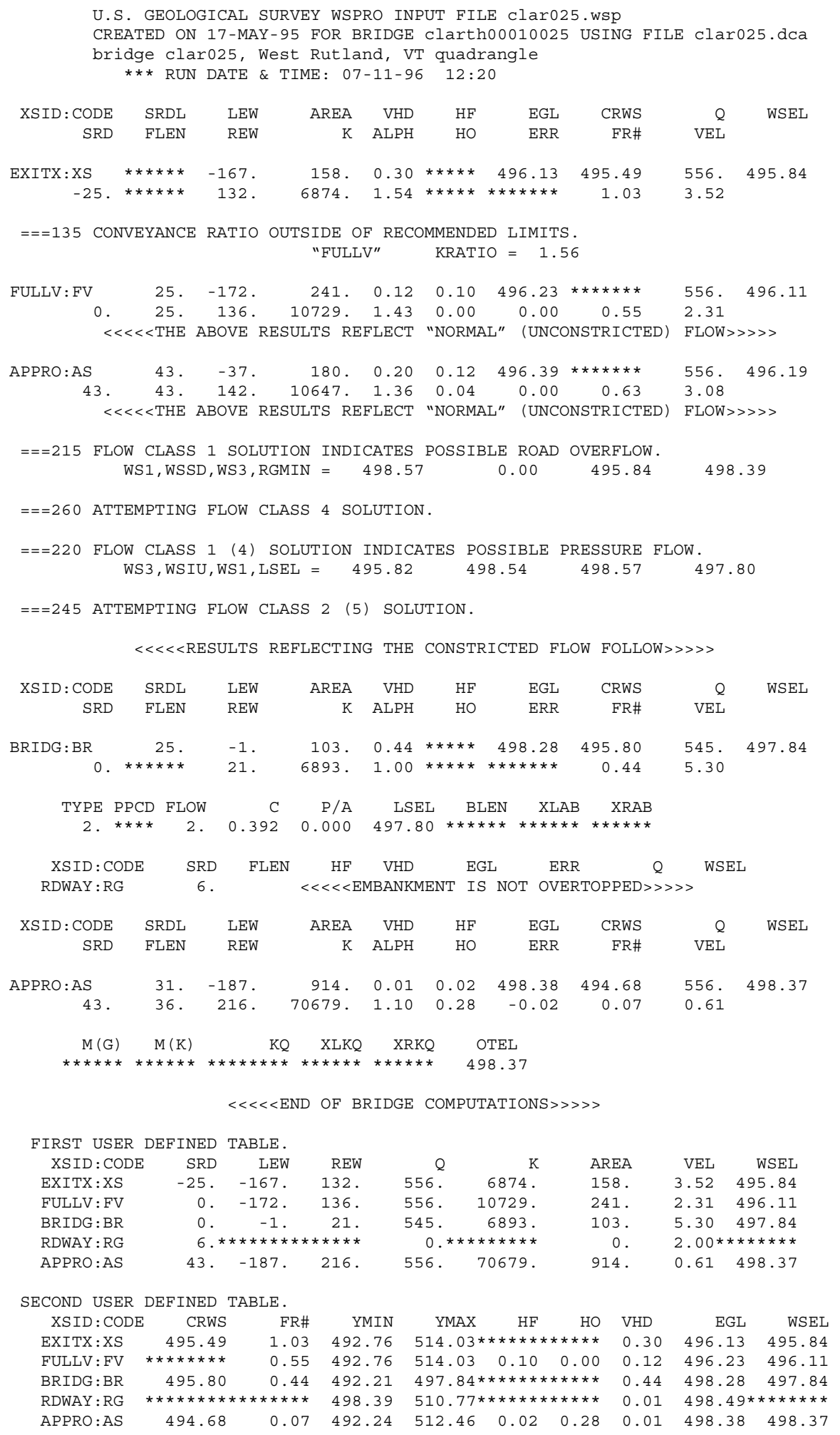




\section{APPENDIX C:}

\section{BED-MATERIAL PARTICAL-SIZE DISTRIBUTION}




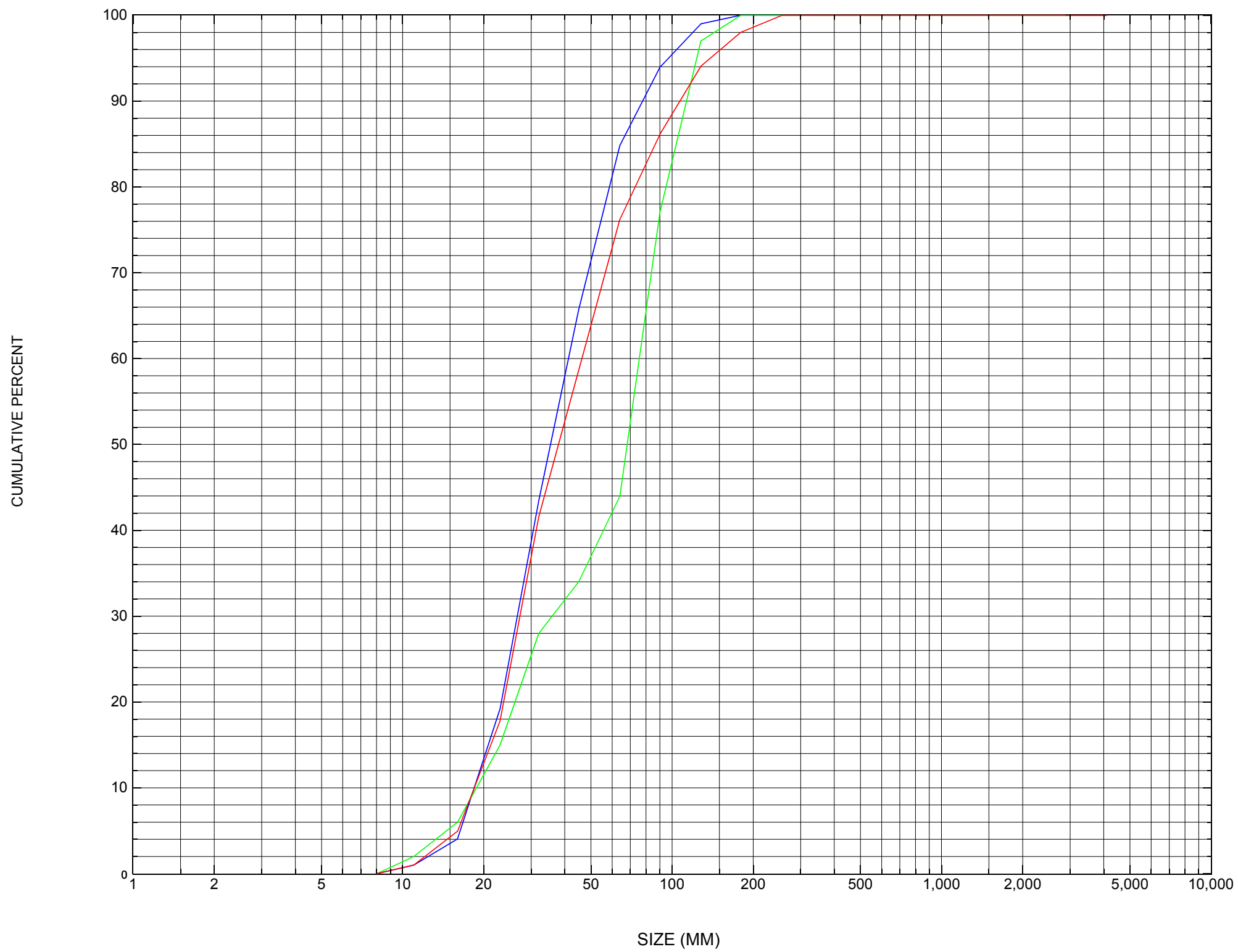

Appendix C. Bed material particle-size distributions for three pebble count transects at the approach cross-section for structure CLARTH00100025, in Clarendon, Vermont. 


\section{APPENDIX D: \\ HISTORICAL DATA FORM}




\section{Structure Number CLARTH00100025}

\section{General Location Descriptive}

Data collected by (First Initial, Full last name) $\mathbf{E}$. BOEHMLER

Date $(M M / D D / Y Y) \_\mathbf{0 3} / \underline{13} / \underline{95}$

Highway District Number (I - 2; nn) $\mathbf{0 3}$

Town (FIPS place code; I - 4; nnnnn) $\mathbf{1 4 5 0 0}$

Waterway (I - 6) CLARENDON RIVER

Route Number $\underline{\text { TH010 }}$

Topographic Map West.Rutland

Latitude (I - 16; nnnn.n) $\mathbf{4 3 3 1 4}$
County (FIPS county code; I - 3; nnn)

Mile marker (I - 11; nnn.nnn) $\mathbf{0 0 0 0 0 0}$

Road Name (I - 7): -

Vicinity (I - 9) 0.15 MI TO JCT W CL2 TH3

Hydrologic Unit Code: $\mathbf{0 2 0 1 0 0 0 2}$

Longitude (i - 17; nnnnn.n) $\mathbf{7 3 0 0 7}$

\section{Select Federal Inventory Codes}

FHWA Structure Number $(I$ - 8) $\mathbf{1 0 1 1 0 5 0 0 2 5 1 1 0 5}$

Maintenance responsibility $(I-21 ; n n) \quad \mathbf{0 3}$

Year built (I - 27; YYYY) 1919

Average daily traffic, ADT (I - 29; nnnnnn) 000290

Year of ADT (I - 30; YY) $\mathbf{9 2}$

Opening skew to Roadway $(I-34 ; n n) \quad \mathbf{0 0}$

Operational status $(I-41 ; X) \underline{\mathbf{K}}$

Structure type (I- 43; nnn) $\mathbf{3 0 2}$

Approach span structure type $(I-44 ; n n n) \quad \mathbf{0 0 0}$

Number of spans (I - 45; nnn) $\mathbf{0 0 1}$

Number of approach spans (I - 46; nnnn) $\mathbf{0 0 0 0}$

Comments:

The structural inspection report of 12/8/94 indicates the structure is a steel stringer type bridge with a wood deck. The report indicates this bridge is currently closed to traffic with barricades blocking each end of the bridge. Hence a full substructural description of condition was not performed. This bridge has been closed since July of 1990 roughly as per office memorandum. 


\section{Bridge Hydrologic Data}

Is there hydrologic data available? $\underline{\mathbf{N}}$ if No, type ctrl-n $h \quad$ VTAOT Drainage area $\left(m i^{2}\right)$ : -

Terrain character:

Stream character \& type: -

Streambed material:

Discharge Data (cfs):

$$
\begin{aligned}
& Q_{2.33}- \\
& Q_{50}-
\end{aligned}
$$

Record flood date $(M M / D D / Y Y)$ :

Estimated Discharge (cfs): Ice conditions (Heavy, Moderate, Light) : -

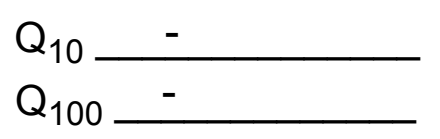

$$
\begin{aligned}
& Q_{25}- \\
& Q_{500}-
\end{aligned}
$$

Water surface elevation $(f t):-$

The stage increases to maximum highwater elevation (Rapidly, Not rapidly):

The stream response is (Flashy, Not flashy):

Describe any significant site conditions upstream or downstream that may influence the stream's stage: -

Watershed storage area (in percent): _ _ \%

The watershed storage area is: - (1-mainly at the headwaters; 2- uniformly distributed; 3-immediatly upstream oi the site)

Water Surface Elevation Estimates for Existing Structure:

\begin{tabular}{|l|l|l|l|l|l|}
\hline Peak discharge frequency & $Q_{2.33}$ & $Q_{10}$ & $Q_{25}$ & $Q_{50}$ & $Q_{100}$ \\
Water surface elevation (ft)) & - & - & - & - & - \\
Velocity (ft/sec) & - & - & - & - & - \\
\hline
\end{tabular}

Long term stream bed changes: -

Is the roadway overtopped below the $\mathrm{Q}_{100}$ ? (Yes, No, Unknown): $\mathbf{U}$ Frequency: Relief Elevation (ft): Discharge over roadway at $Q_{100}\left(f^{3} / \mathrm{sec}\right)$ :

Are there other structures nearby? (Yes, No, Unknown): $\underline{\mathbf{U}}$ Upstream distance (miles): Town: If No or Unknown, type ctrl-n os Highway No. : Structure No. : Year Built:

Clear span (ft): Clear Height $(f t)$ : Full Waterway $\left(f^{2}\right)$ : 
Downstream distance (miles): Town: Year Built:

Highway No. : Structure No. : Structure Type:

Clear span (ft): Clear Height $(f t)$ : Full Waterway $\left(f^{2}\right):$

Comments:

\section{USGS Watershed Data}

Watershed Hydrographic Data

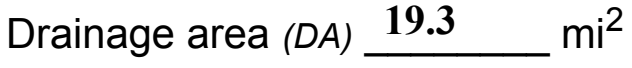

Watershed storage (ST) 6.5

Bridge site elevation 830 Main channel length 12.89 $\mathrm{ft}$ $\%$

Lake and pond area

1.26 $\mathrm{mi}^{2}$ $10 \%$ channel length elevation $\mathbf{9 5 0}$ $\mathrm{ft} \quad 85 \%$ channel length elevation $\mathrm{ft}$
Main channel slope
(S) 19.65 $\mathrm{ft} / \mathrm{mi}$

Watershed Precipitation Data

Average site precipitation in Average headwater precipitation in

Maximum 2yr-24hr precipitation event $(124,2)$

5.5 in

Average seasonal snowfall $(S n) \quad 5.8 \quad \mathrm{ft}$ 


\section{Bridge Plan Data}

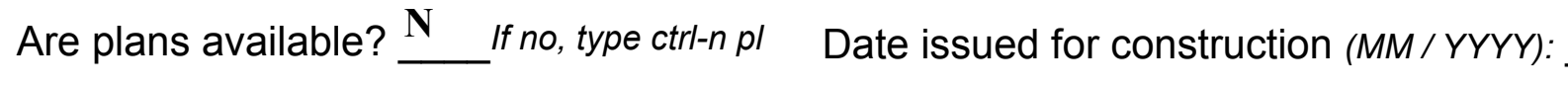

Project Number

Minimum channel bed elevation:

Low superstructure elevation: USLAB DSLAB USRAB DSRAB Benchmark location description:

NO BENCHMARK INFORMATION

Reference Point (MSL, Arbitrary, Other): Datum (NAD27, NAD83, Other):

Foundation Type: 4

If 1: Footing Thickness

If 2: Pile Type: (1-Wood; 2-Steel or metal; 3-Concrete)

If 3 : Footing bottom elevation:

Is boring information available? $\mathbf{N}$ If no, type ctrl-n bi Number of borings taken:

Foundation Material Type: $\mathbf{3}$ (1-regolith, 2-bedrock, 3-unknown)

Briefly describe material at foundation bottom elevation or around piles:

NO FOUNDATION MATERIAL INFORMATION

Comments:

NO PLANS. 


\section{Cross-sectional Data}

Is cross-sectional data available? $\mathbf{N}$ If no, type ctrl-n xs

Source (FEMA, VTAOT, Other)? -

Comments: NO CROSS SECTION INFORMATION

\begin{tabular}{|l|l|l|l|l|l|l|l|l|l|l|l|}
\hline Station & - & - & - & - & - & - & - & - & - & - & - \\
\hline Feature & - & - & - & - & - & - & - & - & - & - & - \\
\hline $\begin{array}{l}\text { Low cord } \\
\text { elevation }\end{array}$ & - & - & - & - & - & - & - & - & - & - & - \\
\hline $\begin{array}{l}\text { Bed } \\
\text { elevation }\end{array}$ & - & - & - & - & - & - & - & - & - & - & - \\
\hline $\begin{array}{l}\text { Low cord to } \\
\text { bed length }\end{array}$ & - & - & - & - & - & - & - & - & - & - & - \\
\hline Station & - & - & - & - & - & - & - & - & - & - & - \\
\hline Feature & - & - & - & - & - & - & - & - & - & - & - \\
\hline $\begin{array}{l}\text { Low cord } \\
\text { elevation }\end{array}$ & - & - & - & - & - & - & - & - & - & - & - \\
\hline $\begin{array}{l}\text { Bed } \\
\text { elevation }\end{array}$ & - & - & - & - & - & - & - & - & - & - & - \\
\hline $\begin{array}{l}\text { Low cord to } \\
\text { bed length }\end{array}$ & - & - & - & - & - & - & - & - & - & - & - \\
\hline
\end{tabular}

Source (FEMA, VTAOT, Other)?

Comments: NO CROSS SECTION INFORMATION

\begin{tabular}{|l|l|l|l|l|l|l|l|l|l|l|l|}
\hline Station & - & - & - & - & - & - & - & - & - & - & - \\
\hline Feature & - & - & - & - & - & - & - & - & - & - & - \\
\hline $\begin{array}{l}\text { Low cord } \\
\text { elevation }\end{array}$ & - & - & - & - & - & - & - & - & - & - & - \\
\hline $\begin{array}{l}\text { Bed } \\
\text { elevation }\end{array}$ & - & - & - & - & - & - & - & - & - & - & - \\
\hline $\begin{array}{l}\text { Low cord to } \\
\text { bed length }\end{array}$ & - & - & - & - & - & - & - & - & - & - & - \\
\hline Station & - & - & - & - & - & - & - & - & - & - & - \\
\hline Feature & - & - & - & - & - & - & - & - & - & - & - \\
\hline $\begin{array}{l}\text { Low cord } \\
\text { elevation }\end{array}$ & - & - & - & - & - & - & - & - & - & - & - \\
\hline $\begin{array}{l}\text { Bed } \\
\text { elevation }\end{array}$ & - & - & - & - & - & - & - & - & - & - & - \\
\hline $\begin{array}{l}\text { Low cord to } \\
\text { bed length }\end{array}$ & - & - & - & - & - & - & - & - & - & - & \\
\hline
\end{tabular}




\section{APPENDIX E: \\ LEVEL I DATA FORM}


U. S. Geological Survey

Bridge Field Data Collection and Processing Form

Qa/Qc Check by: DS Date: $\underline{05 / 05 / 95}$

\section{Structure Number}

\section{A. General Location Descriptive}

1. Data collected by (First Initial, Full last name) M. IVANOFF

2. Highway District Number $\mathbf{0 3}$

Mile marker $\mathbf{0}$

County Rutland (021)

Town Clarendon (14500)

Waterway (I - 6) Clarendon River

Route Number TH 10

Road Name -

3. Descriptive comments:

Hydrologic Unit Code: $\mathbf{0 2 0 1 0 0 0 2}$

0.15 miles to the junction of TH 3 and TH 1.

Bridge deck and steel stringers were removed prior to the inspection.

\section{B. Bridge Deck Observations}
4. Surface cover... LBUS 4
RBUS 4
LBDS 4
RBDS 4
Overall 4

(2b us, ds,lb,rb: 1- Urban; 2- Suburban; 3- Row crops; 4- Pasture; 5- Shrub- and brushland; 6- Forest; 7- Wetland)
5. Ambient water surface... US $\underline{2}$
UB 2
DS $\underline{2}$
(1- pool; 2- riffle)

6. Bridge structure type 1 (1- single span; 2- multiple span; 3- single arch; 4- multiple arch; 5-cylindrical culvert; 6- box culvert; or 7- other)
7. Bridge length $\underline{\mathbf{2 7 . 0}}$
(feet)
Span length $\mathbf{2 4 . 0}$
(feet)
Bridge width 12.2 (feet)

\section{Road approach to bridge:}
8. LB 1 RB $\underline{\mathbf{0}}$
( 0 even, 1- lower, 2- higher)
9. LB 2
RB $\underline{2}$
(1-Paved, 2- Not paved)

10. Embankment slope (run / rise in feet / foot)
US left
2.1:1
US right
2.6:1

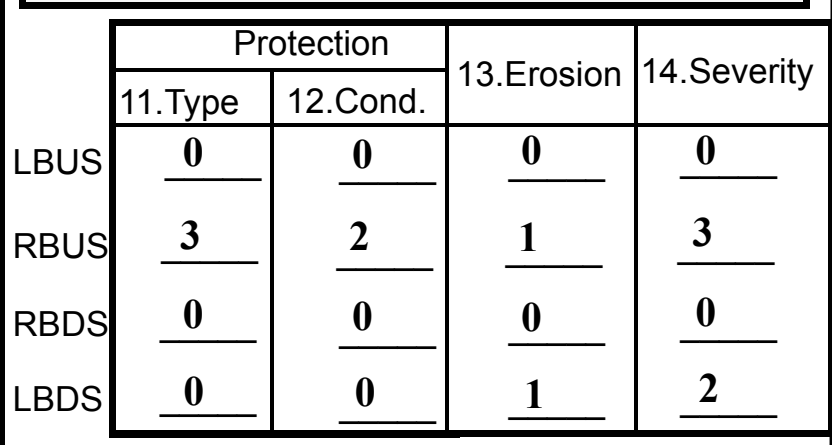

Bank protection types: 0- none; 1- < 12 inches;

2- < 36 inches; 3- < 48 inches;

4- < 60 inches; 5- wall / artificial levee

Bank protection conditions: 1- good; 2- slumped;

3- eroded; 4- failed

Erosion: 0 - none; 1- channel erosion; 2 -

road wash; 3- both; 4- other

Erosion Severity: 0 - none; 1- slight; 2- moderate; 3- severe

\section{Channel approach to bridge (BF):}

15. Angle of approach: $\mathbf{3 0}$

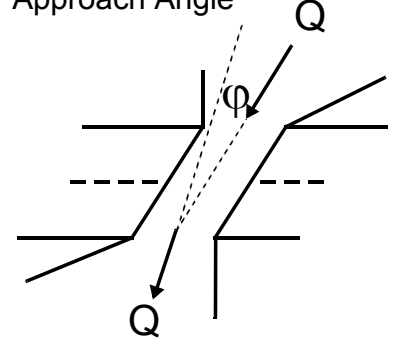

17. Channel impact zone 1 :

Where? RB (LB, RB)

Range? 42 feet US

Channel impact zone 2:

Where? LB $(L B, R B)$

Range? $\underline{6}$ feet $\underline{\mathbf{U B}}$ (US, UB, DS) to $\underline{\mathbf{3 2}}$ feet $\underline{\mathbf{D S}}$

Impact Severity: 0- none to very slight; 1- Slight; 2- Moderate; 3- Severe
16. Bridge skew: 10 Bridge Skew Angle

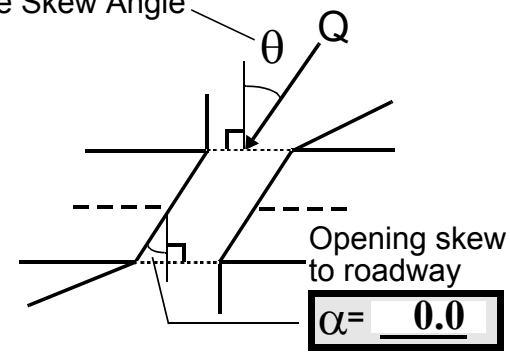

\section{Exist? $\mathbf{Y}(\mathrm{Y}$ or $N)$}

Severity 3

S, UB, DS) to $\underline{4}$ feet $\underline{\mathbf{U S}}$

Exist? $\mathbf{Y}(Y$ or $N)$

Severity $\underline{2}$ 
18. Level II Bridge Type: $\underline{4}$

1a- Vertical abutments with wingwalls

$1 \mathrm{~b}$ - Vertical abutments without wingwalls

2- Vertical abutments and wingwalls, sloping embankment Wingwalls perpendicular to abut. face

3- Spill through abutments

4- Sloping embankment, vertical wingwalls and abutments

Wingwall angle less than $90^{\circ}$.

19. Bridge Deck Comments (surface cover variations, measured bridge and span lengths, bridge type variations, approach overflow width, etc.)

7. Measured bridge length: 28.5 feet, span: 24 feet, and width: 15.5 . The timber deck was resting on the right road approach.

11. RBUS: protection consists of concrete blocks possibly from an old abutment.

13. LBDS: erosion by an apparent 'eddy' current at the downstream end of the left abutment.

17. Impact zone 1: causing severe erosion to the upstream right bank and road embankment.

18. Impact zone 2: 'eddy' current is also impacting the downstream side of the left road approach embankment.

\section{Upstream Channel Assessment}

\begin{tabular}{|c|c|c|c|c|c|c|c|c|c|c|}
\hline \multicolumn{5}{|c|}{ 21. Bank height (BF) 22. Bank angle (BF) } & \multicolumn{2}{|c|}{ 26. \% Veg. cover (BF) } & \multicolumn{2}{|c|}{ 27. Bank material (BF } & \multicolumn{2}{|c|}{ 28. Bank erosion (BF } \\
\hline 20. SRD & LB & RB & LB & RB & LB & $\mathrm{RB}$ & LB & $\mathrm{RB}$ & LB & RB \\
\hline - & 2.0 & & & 3.0 & 1 & 1 & 321 & 321 & 2 & 3 \\
\hline 23. Ban & & & 24. $C$ & el width & 60.0 & 25. The & weg dep & 12.0 & 29. Bed & 321 \\
\hline
\end{tabular}

30 .Bank protection type:

LB 0

RB 0

31. Bank protection condition: LB -

$\mathrm{RB}-$

SRD - Section ref. dist. to US face \% Vegetation (Veg) cover: 1- 0 to 25\%; 2- 26 to 50\%; 3- 51 to $75 \%$; 4- 76 to $100 \%$

Bed and bank Material: 0- organics; 1- silt / clay, <1/16mm; 2- sand, 1/16 - 2mm; 3- gravel, 2 - 64mm;

4- cobble, 64 - 256mm; 5- boulder, > 256mm; 6- bedrock; 7-manmade

Bank Erosion: 0- not evident; 1- light fluvial; 2- moderate fluvial; 3- heavy fluvial / mass wasting

Bank protection types: 0- absent; 1- < 12 inches; 2- < 36 inches; 3- < 48 inches; 4- < 60 inches; 5- wall / artificial levee

Bank protection conditions: 1- good; 2- slumped; 3- eroded; 4- failed

32. Comments (bank material variation, minor inflows, protection extent, etc.):

26. Pasture; tall grasses.

27. Coarse gravel material set in a sandy silt clay; fairly cohesive.

29. Fine to coarse gravel in a sandy silt.

Upstream right bank has a minor road drainage entering the stream. The banks are generally low. The channel makes two 90 degree turns just before entering the bridge opening. 
33.Point/Side bar present? Y

$(Y$ or N. if $N$ type ctrl-n pb) 34 . Mid-bar distance: 165

35. Mid-bar width: 11

36. Point bar extent: 125 feet $\underline{\text { US }}$ (US, UB) to $\underline{\mathbf{1 8 0}}$ feet $\underline{\mathrm{US}}$ (US, UB, DS) positioned $\underline{\mathbf{4 0}} \%$ LB to $\underline{100} \%$ RB

37. Material: 23

38. Point or side bar comments (Circle Point or Side; Note additional bars, material variation, status, etc.):

37. Medium to fine gravel and some sand. No bars closer to the bridge.

39. Is a cut-bank present? $\mathbf{Y}$ ( $Y$ or if $N$ type ctrl-n $c b)$

40. Where? $\underline{\mathbf{R B}}$ (LB or RB)

41. Mid-bank distance: $\mathbf{2 6}$

42. Cut bank extent: 10

43. Bank damage: $\mathbf{3}$

(1- eroded and/or creep; 2- slip failure; 3- block failure)

44. Cut bank comments (eg. additional cut banks, protection condition, etc.):

Numerous locations of block failure. Additional cut-banks are on the right bank 80 to 100 feet upstream and on the left bank 105 to 185 feet upstream; both consist of block failure.

\section{Is channel scour present? $\mathbf{Y}$ ( $Y$ or if $N$ type ctrl-n cs) $\quad$ 46. Mid-scour distance: $\underline{48}$}
47. Scour dimensions: Length $\mathbf{3 6}$
Width 22
Depth : $\underline{\mathbf{3 . 0}}$
Position $\underline{10} \%$ LB to $\underline{90} \%$ RB

48. Scour comments (eg. additional scour areas, local scouring process, etc.):

Eddy pool 24 to 60 feet upstream from the bridge.
49. Are there major confluences? $\mathbf{N}$
( $Y$ or if $N$ type ctrl-n $m c$ )
50. How many? -
51. Confluence 1: Distance -
Confluence 2: Distance -
52. Enters on - ( $L B$ or $R B$ )
Enters on - ( $L B$ or $R B)$
53. Type-__ (1- perennial; 2- ephemeral)
Type __ (1- perennial; 2- ephemeral)

54. Confluence comments (eg. confluence name):

NO MAJOR CONFLUENCES

\section{Under Bridge Channel Assessment}

55. Channel restraint (BF)? LB 2

56. Height (BF)
LB RB
$\mathbf{3 8 . 5}$ RB
58. Bank width (BF) -

59. Channel width $(\mathrm{Amb})$ (1- natural bank; 2- abutment; 3- artificial levee)

Bed and bank Material: 0- organics; 1- silt / clay, < 1/16mm; 2- sand, 1/16 - 2mm; 3- gravel, 2 - 64mm; 4- cobble, 64 - 256mm; 5- boulder, > 256mm; 6- bedrock; 7- manmade

Bank Erosion: 0- not evident; 1- light fluvial; 2- moderate fluvial; 3- heavy fluvial / mass wasting

64. Comments (bank material variation, minor inflows, protection extent, etc.):

321

63. Medium to coarse gravel imbedded in sand and silty clay. 
65. Debris and Ice Is there debris accumulation?

(Yor $N)$ 66. Where? $\mathbf{N}$ (1- Upstream; 2- At bridge; 3- Both)

67. Debris Potential ( 1-Low; 2- Moderate; 3- High) 68. Capture Efficiency 2 (1-Low; 2- Moderate; 3- High) 69. Is there evidence of ice build-up? 2 ( $Y$ or $N)$ Ice Blockage Potential $\mathbf{N}$ (1- Low; 2- Moderate; 3- High)

70. Debris and Ice Comments:

1

67. No debris accumulation near the bridge. The channel is laterally unstable with cut-banks and few trees or vegetation along the banks.

68. Moderate channel gradient. The bridge span length is $60 \%$ of the upstream bank width.

69. The flow angle can increase the ice build up on the right over bank upstream.

\begin{tabular}{|l|c|c|c|c|c|c|c|c|}
\hline Abutments & $\begin{array}{c}\text { 71. Attack } \\
\angle \mathrm{BF})\end{array}$ & $\begin{array}{c}72 . \text { Slope } \\
(\mathrm{Qmax})\end{array}$ & $\begin{array}{l}\text { 73. Toe } \\
\text { loc. (BF) }\end{array}$ & $\begin{array}{c}\text { 74. Scour } \\
\text { Condition }\end{array}$ & $\begin{array}{c}\text { 75. Scour } \\
\text { depth }\end{array}$ & $\begin{array}{c}\text { 76. Exposure } \\
\text { depth }\end{array}$ & 77. Material & 78. Length \\
\hline LABUT & & $\mathbf{1 5}$ & $\mathbf{9 0}$ & $\mathbf{2}$ & $\mathbf{1}$ & $\mathbf{0}$ & $\mathbf{0}$ & $\mathbf{9 0 . 0}$ \\
\hline RABUT & $\mathbf{2}$ & $\mathbf{0}$ & $\mathbf{9 0}$ & & & $\mathbf{2}$ & $\mathbf{0}$ & $\mathbf{2 2 . 5}$ \\
\hline
\end{tabular}

Pushed: $L B$ or RB

Toe Location (Loc.): 0- even, 1- set back, 2- protrudes

Scour cond.: 0- not evident; 1- evident (comment); 2- footing exposed; 3-undermined footing; 4- piling exposed; 5- settled; 6- failed

Materials: 1- Concrete; 2- Stone masonry or drywall; 3- steel or metal; 4- wood

79. Abutment comments (eg. undermined penetration, unusual scour processes, debris, etc.):

0

0

77. LABUT: material consist of cut stone blocks.

74. LABUT: Some of the stone blocks have fallen out of the downstream end of the abutment wall to 6 feet under the bridge. Also the stone below the bridge seat are missing. There is a 2 foot gap (height) between the remaining stones and older concrete.

80. Wingwalls:

$\begin{array}{llll} & & & \\ \text { Exist? Material? } & \text { Scour } & \text { Scour } & \text { Exposure } \\ \text { Condition? } & \text { depth? } & \text { depth? }\end{array}$

USLWW:

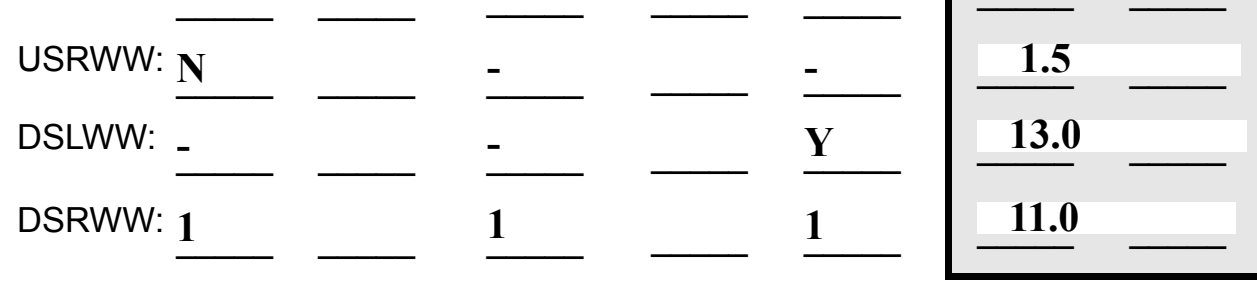

Wingwall materials: 1- Concrete; 2- Stone masonry or drywall; 3- steel or metal; 4- wood

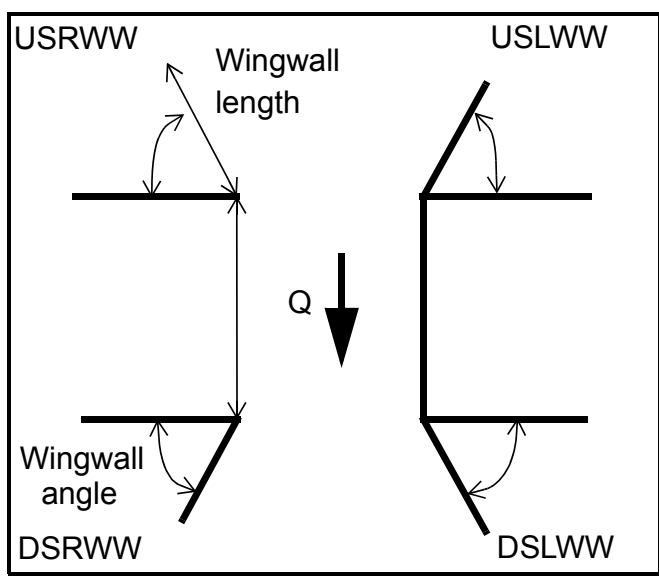

82. Bank / Bridge Protection:

\begin{tabular}{|l|l|l|l|l|l|l|l|c|}
\hline Location & USLWW & USRWW & LABUT & RABUT & LB & RB & DSLWW & DSRWW \\
\hline Type & $\mathbf{0}$ & - & $\mathbf{N}$ & - & - & - & - & - \\
\hline Condition & $\mathbf{N}$ & - & - & - & - & - & - & - \\
\hline Extent & - & - & - & $\mathbf{0}$ & $\mathbf{0}$ & $\mathbf{0}$ & $\mathbf{0}$ & $\mathbf{0}$ \\
\hline
\end{tabular}

Bank / Bridge protection types: 0- absent; 1- < 12 inches; 2- < 36 inches; 3- < 48 inches; 4- < 60 inches; 
83. Wingwall and protection comments (eg. undermined penetration, unusual scour processes, etc.):

-
-
0
-
-
0
-
-
0
-
-

\section{Piers:}

84. Are there piers? $\mathbf{8 0 .}$ ( $Y$ or if $N$ type ctrl-n pr)

\begin{tabular}{|l|l|l|l|l|l|l|l|}
\hline \multirow{2}{*}{$\begin{array}{l}85 . \\
\text { Pier no. }\end{array}$} & \multicolumn{3}{|c|}{ width (w) feet } & \multicolumn{3}{c|}{ elevation (e) feet } \\
\cline { 2 - 9 } & w1 & w2 & w3 & e@w1 & e@w2 & e@w3 \\
\hline Pier 1 & - & & $\mathbf{9 . 0}$ & - & $\mathbf{8 0 . 0}$ & - \\
\hline Pier 2 & - & - & - & - & - & - \\
\hline Pier 3 & - & - & - & - & - & - \\
\hline Pier 4 & - & - & - & - & - & - \\
\hline
\end{tabular}

\begin{tabular}{|l|l|l|l|l|}
\hline Level 1 Pier Descr. & \multicolumn{1}{|c|}{1} & \multicolumn{1}{|c|}{2} & 3 & \multicolumn{1}{|c|}{4} \\
\hline 86. Location (BF) & USR & of & & - \\
\hline 87. Type & WW & the & & - \\
\hline 88. Material & $:$ & wing & N & - \\
\hline 89. Shape & Scou & wall. & - & - \\
\hline 90. Inclined? & r & & - & - \\
\hline 91. Attack $\angle$ (BF) & dept & & - & - \\
\hline 92. Pushed & h is & & - & - \\
\hline 93. Length (feet) & - & - & - & - \\
\hline 94. \# of piles & at & & - & - \\
\hline 95. Cross-members & the & & - & - \\
\hline 96. Scour Condition & upst & & - & - \\
\hline 97. Scour depth & ream & & - & - \\
\hline 98. Exposure depth & end & & - & - \\
\hline
\end{tabular}

LFP, LTB, LB, MCL, MCM, MCR, RB, RTB, RFP

1- Solid pier, 2-column, 3- bent

1-Wood; 2- concrete; 3- metal; 4- stone

1- Round; 2- Square; 3- Pointed

Y-yes; $N-$ no

$L B$ or $R B$

0- none; 1- laterals; 2- diagonals; 3- both

0- not evident; 1- evident (comment);

2- footing exposed; 3- piling exposed;

4- undermined footing; 5- settled; 6-failed 
99. Pier comments (eg. undermined penetration, protection and protection extent, unusual scour processes, etc.):

-
-
-
-
-
-
-
-
-
-

100.

\section{E. Downstream Channel Assessment}

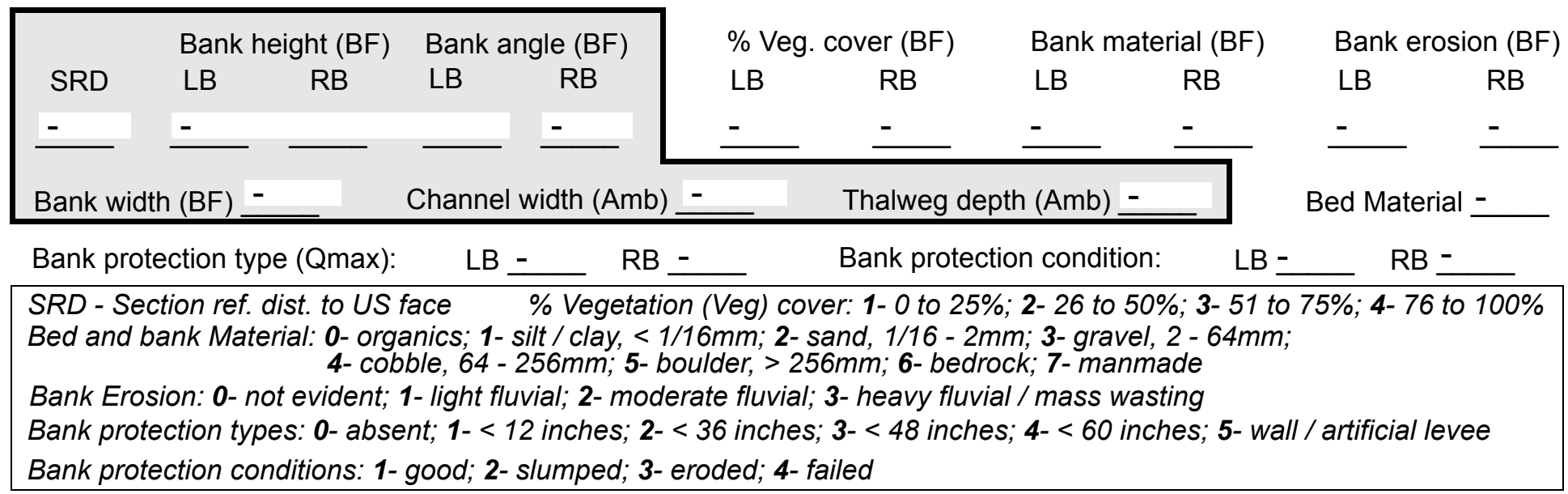

Comments (eg. bank material variation, minor inflows, protection extent, etc.):

-

NO PIERS

101. Is a drop structure present? (Y or $N$, if $N$ type ctrl-n ds)

102. Distance: - feet

103. Drop: __ feet 104. Structure material: 1 (1- steel sheet pile; 2- wood pile; 3- concrete; 4- other) 105. Drop structure comments (eg. downstream scour depth):

1

321

321

2

1

3214 
106. Point/Side bar present? 0 (Y or $N$. if $N$ type ctrl-n pb)Mid-bar distance: $\mathbf{0}$ Mid-bar width: -

Point bar extent: feet $\underline{\mathbf{B a}}$ (US, UB, DS) to $\underline{\mathbf{n k}}$ feet $\underline{\mathbf{m a}}$

US, UB, DS) DS) positioned teri \% $\%$ LB to a $\%$ RB

Material: con

Point or side bar comments (Circle Point or Side; note additional bars, material variation, status, etc.):

sists of gravels with sand, silt, and clay.

Bed material consists of fine to coarse gravel embedded in sand, silt/ clay with random cobbles.

Uniform channel slope.

Is a cut-bank present? (Y or if $N$ type ctrl- $n$ cb) Where? (LB or $R B)$

Mid-bank distance:

Cut bank extent: feet (US, UB, DS) to feet (US, UB, DS)

Bank damage: (1- eroded and/or creep; 2- slip failure; 3- block failure)

Cut bank comments (eg. additional cut banks, protection condition, etc.):

$\mathbf{N}$

Is channel scour present? ( $Y$ or if $N$ type ctrl-n cs)

Mid-scour distance: NO

$$
\text { Scou }
$$

Are there major confluences? R Confluence 2: Distance 6 Confluence comments (eg. confluence name):

DS

50

\title{
F. Geomorphic Channel Assessment
}

\author{
107. Stage of reach evolution $\mathbf{8 0}$ \\ 1- Constructed \\ 2- Stable \\ 3- Aggraded \\ 4- Degraded \\ 5- Laterally unstable \\ 6- Vertically and laterally unstable
}


108. Evolution comments (Channel evolution not considering bridge effects; See HEC-20, Figure 1 for geomorphic descriptors):

3

Material is fine to medium gravel with some sand and silt. Apparently eroded by the channel along the right bank; slight anabranching. The bar is slightly vegetated.

Y

LB

32

10

DS

61

DS

3 


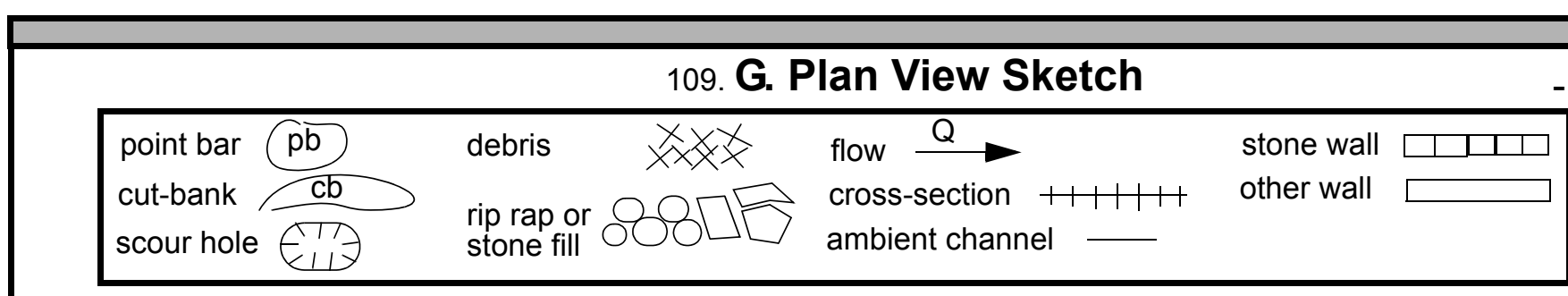


APPENDIX F:

SCOUR COMPUTATIONS 
SCOUR COMPUTATIONS

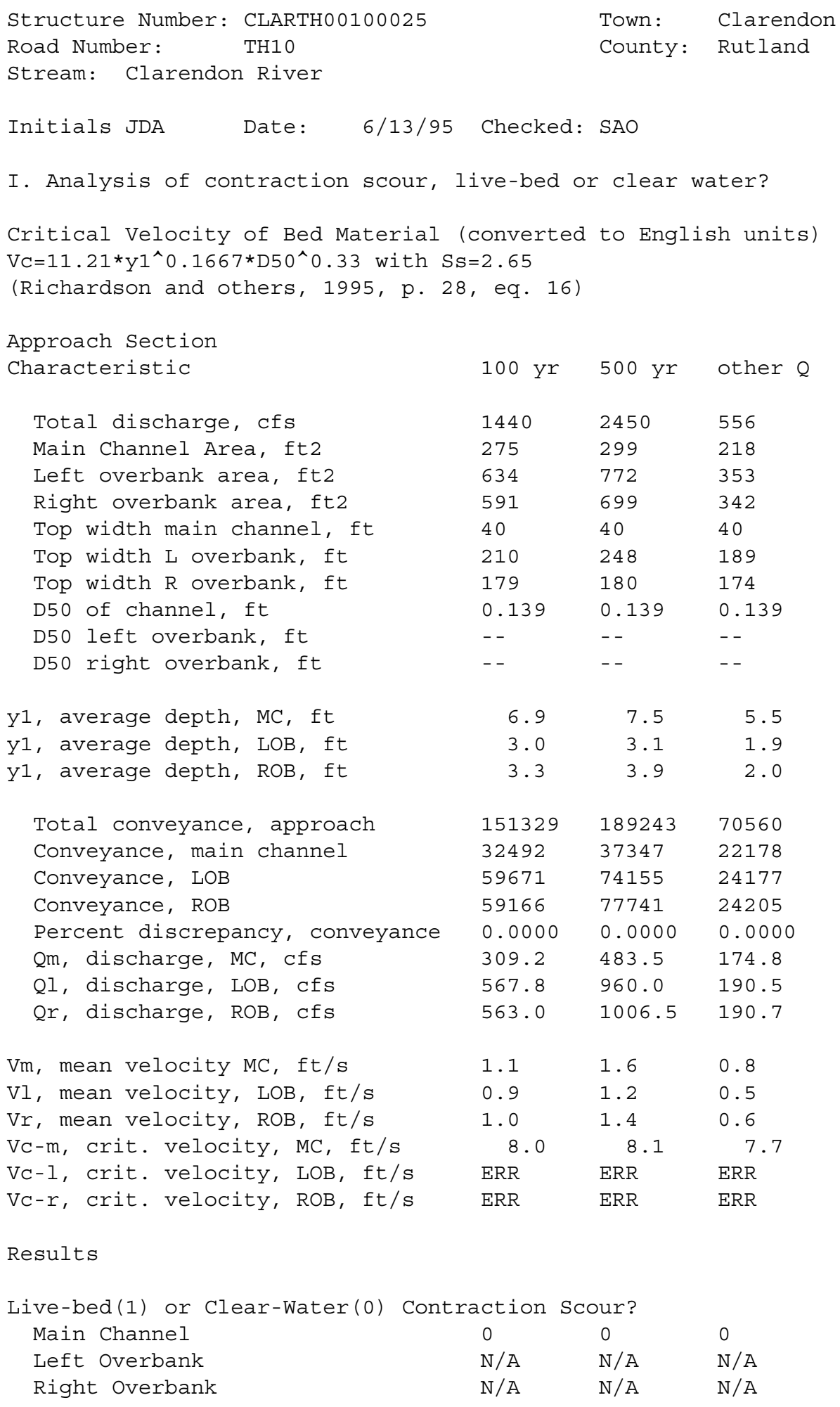


Clear Water Contraction Scour in MAIN CHANNEL

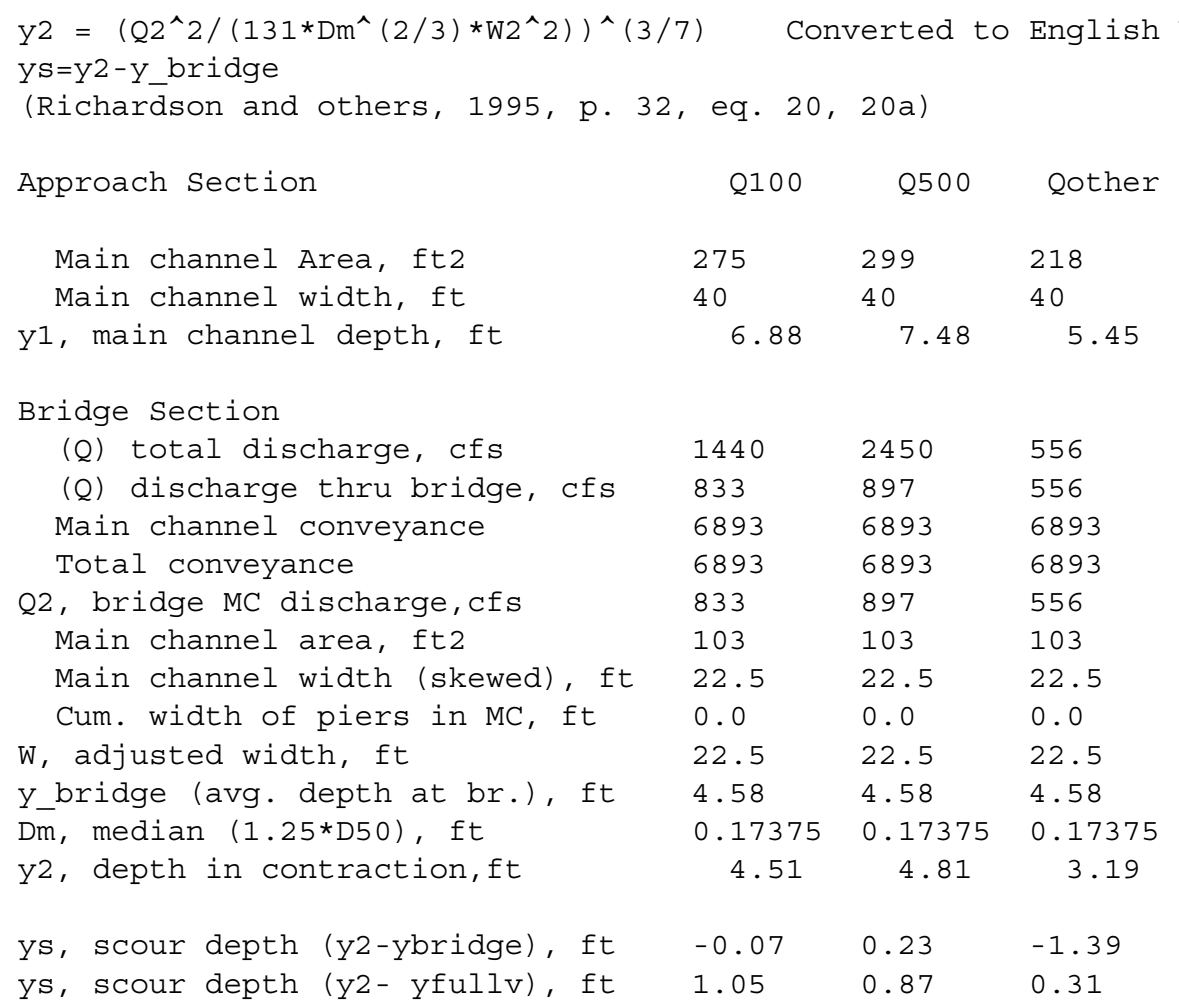

Pressure Flow Scour (contraction scour for orifice flow conditions)

\begin{tabular}{|c|c|c|c|}
\hline $\mathrm{Hb}+\mathrm{Ys}=\mathrm{Cq} * \mathrm{qbr} / \mathrm{Vc} \quad \mathrm{Cq}=1 / \mathrm{Cf} * \mathrm{Cc}$ & $\mathrm{Cf}=1$ & $5 * \operatorname{Fr}^{\wedge} 0.43$ & $(<=1)$ \\
\hline $\begin{array}{l}\text { Chang Equation CC=SQRT }[0.1 \\
\text { (Richardson and others, 1995, p. }\end{array}$ & $\begin{array}{l}\mathrm{Hb} /(\mathrm{ya}-\mathrm{w})- \\
-146)\end{array}$ & $-0.56)]+0$ & $79 \quad(<=1)$ \\
\hline & Q100 & Q500 & OtherQ \\
\hline Q thru bridge main chan, cfs & 833 & 897 & 556 \\
\hline Vc, critical velocity, ft/s & 8 & 8.1 & 7.7 \\
\hline Vc, critical velocity, m/s & 2.438281 & 2.46876 & 2.346845 \\
\hline Main channel width (skewed), ft & 22.5 & 22.5 & 22.5 \\
\hline Cum. width of piers, ft & 0 & 0 & 0 \\
\hline W, adjusted width, ft & 22.5 & 22.5 & 22.5 \\
\hline qbr, unit discharge, $f t^{\wedge} 2 / \mathrm{s}$ & 37.02222 & 39.86667 & 24.71111 \\
\hline qbr, unit discharge, $\mathrm{m}^{\wedge} 2 / \mathrm{s}$ & 3.439141 & 3.703373 & 2.295513 \\
\hline Area of full opening, $\mathrm{ft}^{\wedge} 2$ & 102.8 & 102.8 & 102.8 \\
\hline Hb, depth of full opening, ft & 4.568889 & 4.568889 & 4.568889 \\
\hline Hb, depth of full opening, m & 1.392529 & 1.392529 & 1.392529 \\
\hline Fr, Froude number MC & 0.67 & 0.72 & 0.44 \\
\hline Cf, Fr correction factor $(<=1$ & 1 & 1 & 1 \\
\hline
\end{tabular}




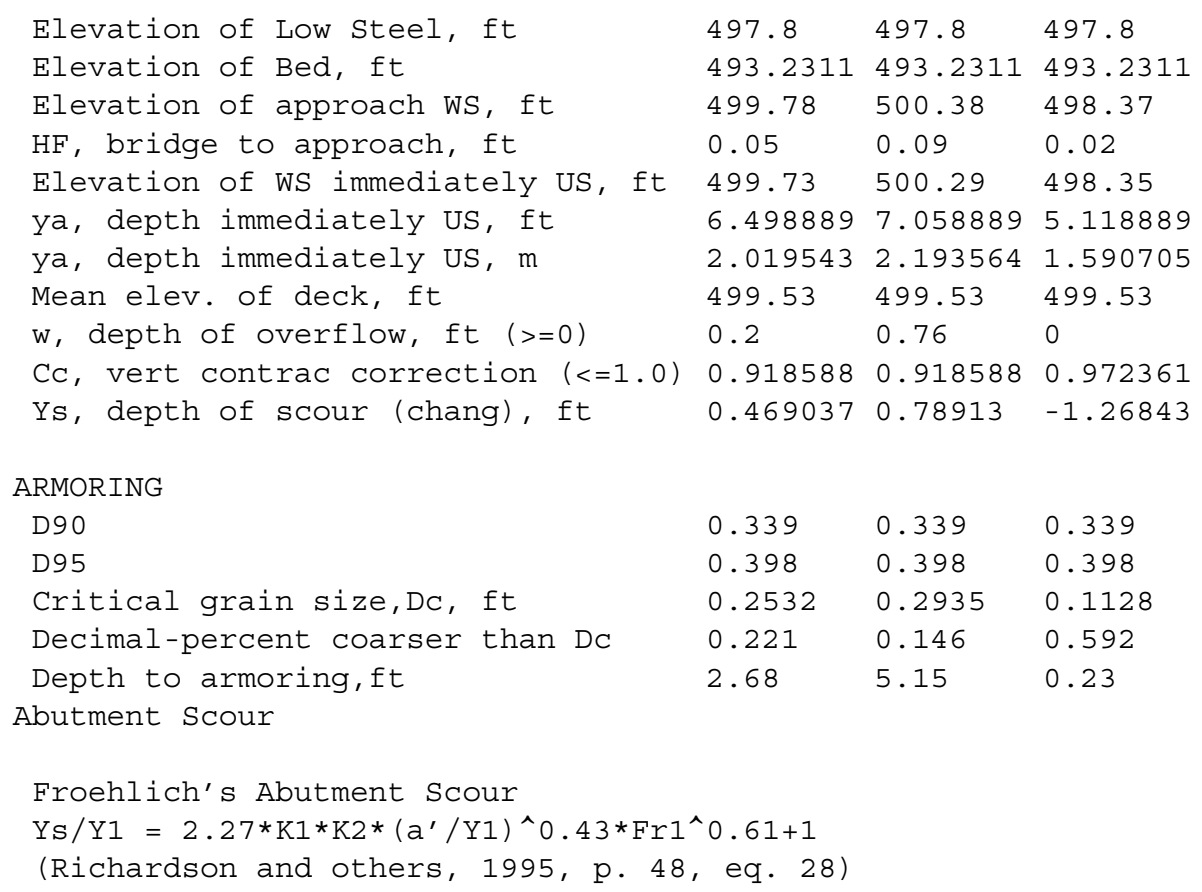



spill-through
4.67
4.67
3.12
5.98
7.09
3.87

Abutment riprap Sizing

Isbash Relationship

$\mathrm{D} 50=\mathrm{Y} * \mathrm{~K} * \mathrm{Fr} \wedge 2 /(\mathrm{Ss}-1)$ and $\mathrm{D} 50=\mathrm{Y} * \mathrm{~K} *\left(\mathrm{Fr}{ }^{\wedge} 2\right)^{\wedge} 0.14 /(\mathrm{Ss}-1)$

(Richardson and others, 1995, p112, eq. 81,82)

\begin{tabular}{|c|c|c|c|c|c|c|}
\hline Characteristic & Q100 & Q500 & Qothe & & & \\
\hline Fr, Froude Number & 0.67 & 0.72 & 0.44 & 0.67 & 0.72 & 0.44 \\
\hline (Fr from the characteristic $V$ and & $y$ in & cracte & ection & $\therefore$ bri & secti & \\
\hline$y$, depth of flow in bridge, ft & 4.58 & 4.58 & 4.58 & 4.58 & 4.58 & 4.58 \\
\hline Median Stone Diameter for riprap at: & : left & atment & & right & atment & \\
\hline Fr< $<0.8$ (vertical abut.) & 1.27 & 1.47 & 0.55 & 1.27 & 1.47 & 0.55 \\
\hline Fr>0.8 (vertical abut.) & ERR & ERR & ERR & ERR & ERR & ERR \\
\hline Fr $<=0.8$ (spillthrough abut.) & 1.11 & 1.28 & 0.48 & 1.11 & 1.28 & 0.48 \\
\hline Fr>0.8 (spillthrough abut.) & ERR & ERR & ERR & ERR & ERR & ERR \\
\hline
\end{tabular}

